\title{
Rapid and Automated Analytical Methods for Redox Species Based on Potentiometric Flow Injection Analysis Using Potential Buffers
}

\author{
Hiroki Ohura $^{1}$ and Toshihiko Imato ${ }^{2}$ \\ ${ }^{1}$ Department of Applied Chemistry and Biochemistry, Faculty of Engineering, Kyushu Sangyo University, Fukuoka 813-8503, Japan \\ ${ }^{2}$ Department of Applied Chemistry, Graduate School of Engineering, Kyushu University, Fukuoka 819-0395, Japan
}

Correspondence should be addressed to Hiroki Ohura, ooura@ip.kyusan-u.ac.jp

Received 13 October 2010; Revised 20 January 2011; Accepted 7 February 2011

Academic Editor: Ricardo Jorgensen Cassella

Copyright ( $) 2011 \mathrm{H}$. Ohura and T. Imato. This is an open access article distributed under the Creative Commons Attribution License, which permits unrestricted use, distribution, and reproduction in any medium, provided the original work is properly cited.

\begin{abstract}
Two analytical methods, which prove the utility of a potentiometric flow injection technique for determining various redox species, based on the use of some redox potential buffers, are reviewed. The first is a potentiometric flow injection method in which a redox couple such as $\mathrm{Fe}(\mathrm{III})-\mathrm{Fe}(\mathrm{II}), \mathrm{Fe}(\mathrm{CN})_{6}{ }^{3-}-\mathrm{Fe}(\mathrm{CN})(\mathrm{CN})_{6}{ }^{4-}$, and bromide-bromine and a redox electrode or a combined platinum-bromide ion selective electrode are used. The analytical principle and advantages of the method are discussed, and several examples of its application are reported. Another example is a highly sensitive potentiometric flow injection method, in which a large transient potential change due to bromine or chlorine as an intermediate, generated during the reaction of the oxidative species with an Fe(III)-Fe(II) potential buffer containing bromide or chloride, is utilized. The analytical principle and details of the proposed method are described, and examples of several applications are described. The determination of trace amounts of hydrazine, based on the detection of a transient change in potential caused by the reaction with a Ce(IV)-Ce(III) potential buffer, is also described.
\end{abstract}

\section{Introduction}

Titrimetric analysis, the characteristics of which include a high precision and the measurement of an absolute quantity, is in widespread use in the chemical industry and the pharmaceutical industry $[1,2]$, and a wide variety of applications have been developed. However, a titrimetric analysis, while a versatile technique, is time-consuming. It is particularly tedious when the rate of the titration reaction is slow, since the operation must wait for a steady reading, even when an automatic-titrator is used. A promising approach to achieve more rapid throughput for analyses required in various fields is the application of flow titration techniques. The flow titration method has been reported by many investigators [3-9]. In the continuous flow titration method, Nagy et al. [5] developed the "triangle-programmed titration technique" and applied it to an argentometric titration. Continuous flow titration, namely, the gas-segmented flow technique, is somewhat complicated and cumbersome in terms of both the apparatus used and the procedures required, in comparison with the nongas-segmented flow injection analysis (FIA), because, in the gas-segmented flow method, the streams need to be debubbled before detection. Thus, flow injection analysis (FIA) [10] has been applied to titration analysis, in attempts to shorten and simplify this time-consuming procedure. Růžička and Hansen [6, 7] reported on an FIA titration method based on the measurement of peak widths. Åström [8] reported on a flow analysis method using both a universal buffer solution and a glass electrode, which was designed to give a linear $\mathrm{pH}$-response to the sample concentration, referred to as a "single point titration." One of authors also proposed an FIA titration method for the determinations of acids and bases or metal ions, which involved the reaction of the sample with a $\mathrm{pH}$ buffer or a metal buffer solution containing an indicator and applied the method to potentiometric detection using a glass electrode or metal ion-selective electrode $[11,12]$. 
We recently proposed an FIA titration method for determination of various redox species utilizing a redox reaction with some redox potential buffers and applied the method to potentiometric detection using a redox electrode. The idea of our proposed FIA titration is the use of characteristics of the potential buffer solution, in which the potential change due to redox reaction of an analyte with the buffer component is directly proportional to the analyte concentration. In addition the potential of the redox electrode is very stable in the potential buffer solution. In this paper, the proposed potentiometric FIA method is discussed, and the subject is divided into two sections. First, we describe a potentiometric FIA method for the determination of redox species using a simple redox reaction of a sample with a potential buffer solution consisting of a redox couple such as $\mathrm{Fe}(\mathrm{III})-\mathrm{Fe}(\mathrm{II})$ or $\mathrm{Fe}(\mathrm{CN})_{6}{ }^{3-}-\mathrm{Fe}(\mathrm{CN})_{6}{ }^{4-}$. This method is based on the detection of a change in the potential of a redox electrode caused by a change in the composition of the potential buffer solution after completion of a reaction between the sample and the potential buffer. Some similar papers that preceeded our method have been published by Porter and Sawyer [13], Brunt [14], and Karlberg and Thelander [15] with respect to the determination of redox species by potentiometry employing a redox reaction in an FIA system. Porter and Sawyer [13] and Brunt [14] reported the determination of glucose and other reducing sugars based on changes in the redox potentials of an $\mathrm{Fe}(\mathrm{CN})_{6}{ }^{3-}-\mathrm{Fe}(\mathrm{CN})_{6}{ }^{4-}$ buffer solution caused by the reaction of sugars with $\mathrm{Fe}(\mathrm{CN})_{6}{ }^{3-}$. Karlberg and Thelander [15] reported the determination of $\mathrm{Fe}(\mathrm{II})$ and ascorbic acid by monitoring the composition of $\mathrm{Ce}(\mathrm{IV})-\mathrm{Ce}(\mathrm{III})$ formed by a reaction with a stream of a cerium(IV) reagent with redox detection. These potentiometric detection methods can be performed with only the use of an oxidant without a reductant as the stream of reagent solution in a flow system. On the contrary, our proposed method involves the use of a potential buffer solution consisting of a redox couple, which stabilizes the measuring potential of the redox electrode. The advantages of the proposed method are that samples in a wide concentration range can be determined by selecting an appropriate concentration of potential buffer solution. In this paper, applications of the proposed method to the rapid determination of redox compounds such as concentrated hydrogen peroxide, ethanol in alcoholic beverages, reducing sugars, manganese(II), and phenol are discussed.

On the other hand, the excellent characteristics of the FIA method permits its use in detecting a final product at an equilibrium state as well as a transient intermediate that appears before chemical equilibrium is reached, where an appropriate chemical reaction is employed. Among the many redox reactions, there are several reactions in which an intermediate compound with a short lifetime is generated. In such a case, the FIA method would be useful for detecting such an intermediate, since a reaction time can be easily controlled in the flow system. During our research on the use of potentiometric FIA for the determination of redox species using a potential buffer, as described above, we discovered an interesting phenomena in which a large transient potential change in the redox electrode with a mountainshape appeared, when a bromate solution was added to an $\mathrm{Fe}(\mathrm{III})-\mathrm{Fe}(\mathrm{II})$ potential buffer containing bromide [16]. The large change in potential was found to be due to bromine generated during the redox reaction of an analyte with the potential buffer, as an intermediate. The electrode potential of the intermediate, bromine/bromide, is much higher than that of the potential buffer. Therefore, in the case of potentiometric FIA, a highly sensitive determination of the analyte can be achieved, provided that the intermediate substance in the FIA system can be detected. No report of a highly sensitive potentiometric FIA method for the determination of oxidative species involving the detection of an intermediate formed during a redox reaction has appeared, so far.

Second, we describe a highly sensitive potentiometric FIA method based on the detection of a large transient potential change in the redox electrode, which appears a short period after an analyte is mixed with the potential buffer. In the case where an $\mathrm{Fe}(\mathrm{III})-\mathrm{Fe}(\mathrm{II})$ potential buffer is used, it was found that the addition of bromide or chloride to the potential buffer enhances the sensitivity for various oxidizing species such as bromate, chromium (VI), hydrogen peroxide, and oxychlorine. A high sensitivity to such oxidative species was achieved by the potentiometric detection of a large transient potential change due to the generation of intermediate bromine or chlorine during the reaction of the analyte with bromide or chloride in the potential buffer. The advantage of the proposed method, in which the detection of an intermediate is involved, is that the bromide or chloride in the $\mathrm{Fe}(\mathrm{III})$ - $\mathrm{Fe}$ (II) potential buffer functions as a homogeneous catalyst for the formation of bromine or chlorine as an intermediate during the reaction. Thus, the proposed method was also applied to the rapid and highly sensitive determination of redox compounds in actual samples, such as residual chlorine in tap water, chromium (VI) in seawater, and hydrazine in boiler water.

Furthermore, the analytical methodology and mechanism for the potential change of the two proposed methods indicate that, in both cases, an equilibrium potential reached after a simple redox reaction and a transient potential generated during a complexed redox reaction could be measured.

\section{Experimental}

A typical two-channel flow system for the determination of redox species is shown in Figure 1. The flow-injection apparatus consisted of a peristaltic pump (Model Minipuls 2, Gilson), a sample injector (HPV6, GLC Sciences Co.), a flowthrough type redox electrode detector (Model FLC-11, DKK Co.) equipped with a platinum or gold plate electrode and a silver/silver chloride reference electrode, and a potentiometer (Model IOC 10, DKK Co.) for measuring the potential of the electrode detector. The manifold was constructed of Teflon tubing $(0.5 \mathrm{~mm}$ i.d.) throughout. A potential buffer solution consisting of an $\mathrm{Ox}_{1}-\mathrm{Red}_{1}$ mixture, such as $\mathrm{Fe}(\mathrm{III})-\mathrm{Fe}(\mathrm{II})$, $\mathrm{Fe}(\mathrm{CN})_{6}{ }^{3-}-\mathrm{Fe}(\mathrm{CN})_{6}{ }^{4-}$, and $\mathrm{Ce}(\mathrm{IV})-\mathrm{Ce}(\mathrm{III})$ was pumped through the reagent channel $\left(\mathrm{V}_{\text {Buff }}\right)$. The potential change of the electrode detector was recorded as a peak-shaped signal, 


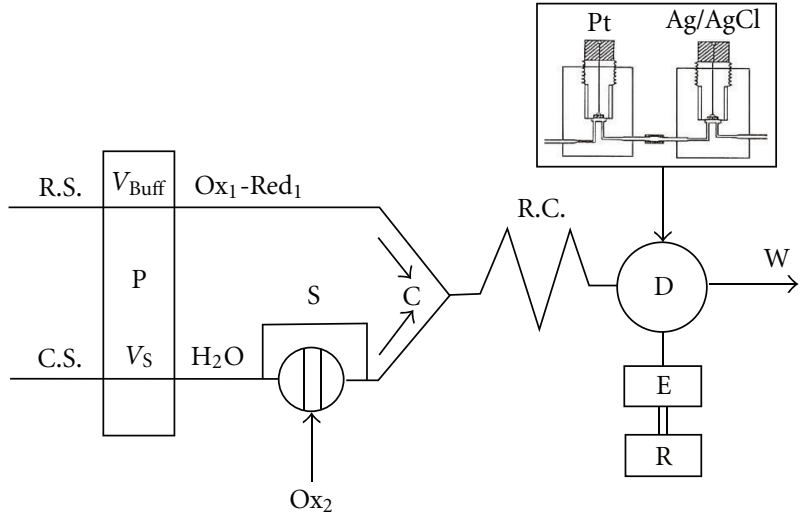

FIGURE 1: Manifolds for the FIA of oxidative and reductive species using a potential buffer solution. R.S.: reagent solution (a mixture of $\left.\mathrm{Ox}_{1}-\mathrm{Red}_{1}\right) ; \mathrm{Ox}_{1}-\mathrm{Red}_{1}$ : oxidants and reductants; C.S.: carrier $\left(\mathrm{H}_{2} \mathrm{O}\right)$; $\mathrm{P}$ : peristaltic pump; $\mathrm{Ox}_{2}$ : oxidative sample; $\mathrm{S}$ : sample injector; $\mathrm{C}$ : confluence point; R.C.: reaction coil; D: flow-through type redox electrode detector; E: potentiometer; R: recorder; W: waste. $V_{\text {Buff }}$ and $V_{\mathrm{S}}$ are flow rates of a buffer solution and water, respectively.

and the concentration of the sample, $\mathrm{Ox}_{2}$, can be determined from the peak height.

Standard analyte solutions of oxidative or reductive substances were prepared by dissolving the corresponding analytical-reagent grade reagents in deionized water. The potential buffer solutions consisting of $\mathrm{Fe}(\mathrm{III})-\mathrm{Fe}(\mathrm{II})$, $\mathrm{Fe}(\mathrm{CN})_{6}{ }^{3-}-\mathrm{Fe}(\mathrm{CN})_{6}{ }^{4-}$, and $\mathrm{Ce}(\mathrm{IV})-\mathrm{Ce}(\mathrm{III})$ were prepared by dissolving of ammonium iron(III) and ammonium iron(II), potassium hexacyanoferrate(III) and potassium hexacyanoferrate(II), and sulfate cerium(IV) and sulfate cerium(III) in dilute sulfuric acid or a sodium hydroxide solution, respectively.

\section{Potential Buffers Consisting of a Redox Couple, and the Characteristics of the Electrode Potential Using a Potential Buffer in FIA}

It is desirable for the potential buffer solution, consisting of a redox couple, employed in the proposed method to be reversible electrochemically and to obey the Nernst equation. The reactivity of a redox sample with one of the redox couples in the potential buffer can be estimated by the order of the magnitude of $E_{0}$ of the redox couple in the potential buffer. The redox electrode showed a Nernstian response to an $\mathrm{Fe}(\mathrm{III})-\mathrm{Fe}(\mathrm{II})$ couple $\left(E_{0}=0.77 \mathrm{~V}\right.$ versus NHE) and a $\mathrm{Ce}(\mathrm{IV})-\mathrm{Ce}(\mathrm{III})$ couple $\left(E_{0}=1.68 \mathrm{~V}\right)$ in an acidic solution and to an $\mathrm{Fe}(\mathrm{CN})_{6}{ }^{3-}-\mathrm{Fe}(\mathrm{CN})_{6}{ }^{4-}$ couple $\left(E_{0}=0.36 \mathrm{~V}\right)$ in a basic solution in the range of concentration ratio of the oxidized form to the reduced form from 0.1 to 10 in the each redox couple, according to (2). In particular, the redox electrode showed a Nernstian response in the $\mathrm{Fe}(\mathrm{CN})_{6}{ }^{3-}$ $\mathrm{Fe}(\mathrm{CN})_{6}{ }^{4-}$ potential buffer, even at a lower concentration down to $10^{-5} \mathrm{M}$. On the other hand, the redox electrode did not show a stable potential to $\mathrm{Cr}(\mathrm{VI})-\mathrm{Cr}(\mathrm{III})$ and $\mathrm{Mn}$ (VII)$\mathrm{Mn}(\mathrm{II})$ couples which are typically employed as a titrant of redox titrimetry. In the case of an $\mathrm{Mn}$ (VII)-Mn(II) couple, when the concentration of the couple was higher than $10^{-3} \mathrm{M}$, the precipitation of $\mathrm{MnO}_{2}$ occurred. This may be due to the fact that a disproportionation reaction occurs in the mixed solution of the redox couple.

The characteristics of the electrode potential which detected the composition of the potential buffer solution in the proposed FIA are summarized as follows.

(1) The baseline potential is stable, and the response is reproducible in the buffer solution, even at low concentrations, because an electrode is immersed in a well-defined potential buffer solution.

(2) For a small change in the composition of a buffer solution, a potential change, namely, the peak height, is nearly proportional to the concentration of a sample.

(3) A wide concentration range can be measured, although the measurable concentration level depends on the concentration of the buffer solution used.

(4) The method has potential applications to liquid chromatography.

\section{Analytical Methodology for a Potentiometric Flow Method by Redox Couple Potential Buffer}

4.1. Equilibrium Potential Change of a Redox Electrode after Simple Redox Reaction with Potential Buffer. In the flow system shown in Figure 1, when an oxidative species, $\mathrm{Ox}_{2}$, as a sample, is injected into a carrier channel, where water is pumped at flow rate of $V_{\mathrm{S}}$, and mixed with the potential buffer solution consisting of a redox couple, $\mathrm{Ox}_{1}-\mathrm{Red}_{1}$, the following redox reaction occurs in the FIA system:

$$
\mathrm{Ox}_{2}+m \operatorname{Red}_{1} \longrightarrow \operatorname{Red}_{2}+m \mathrm{Ox}_{1}
$$

where $m$ is the number of moles of $\operatorname{Red}_{1}$ required to reduce 1 mole of $\mathrm{Ox}_{2}$. The potential of the redox electrode $\left(E_{1}\right.$ in milivolt) in the detector is governed by the concentration ratio of the potential buffer solution and is expressed by the Nernst equation, as shown in (2),

$$
E_{1}=E_{0}+\left(\frac{59}{n}\right) \log \left(\frac{\left[\mathrm{Ox}_{1}\right]}{\left[\operatorname{Red}_{1}\right]}\right) \quad\left(\mathrm{mV}, 25^{\circ} \mathrm{C}\right),
$$

where $E_{0}$ is the formal redox potential, and $n$ is the number of moles of electrons involved in the electrode reaction, and $\left[\mathrm{Ox}_{1}\right]$ and $\left[\operatorname{Red}_{1}\right]$ are the concentrations of $\mathrm{Ox}_{1}$ and $\operatorname{Red}_{1}$, respectively. The baseline potential, $E_{1}$ (the potential when a sample is not injected), can be written in terms of the initial concentrations of $\mathrm{Ox}_{1}$ and $\operatorname{Red}_{1}$, based on (2). In the case where the sample, $\mathrm{Ox}_{2}$, is injected, the redox potential, $E_{2}$, can be expressed as follows under the assumption that reaction (1) is complete before the sample zone reaches the detector when the flow rates of $V_{\text {Buff }}$ and $V_{\mathrm{S}}$ are equal:

$$
E_{2}=E_{0}+\left(\frac{59}{n}\right) \log \left\{\frac{\left[\mathrm{Ox}_{1}\right]+m\left[\mathrm{Ox}_{2}\right]}{\left[\operatorname{Red}_{1}\right]-m\left[\mathrm{Ox}_{2}\right]}\right\} \quad(\mathrm{mV}),
$$


where $\left[\mathrm{Ox}_{2}\right]$ is the initial concentration of $\mathrm{Ox}_{2}$. Under the assumption that no dispersion of the sample and reaction products occur while flowing through the manifold, the potential change $(\Delta E)$ (peak height) of the redox electrode can be expressed by the following equation, which is derived from (2) and (3):

$$
\Delta E=\left(\frac{59}{n}\right) \log \left\{\frac{\left(1+m\left[\mathrm{Ox}_{2}\right] /\left[\mathrm{Ox}_{1}\right]\right)}{\left(1-m\left[\mathrm{Ox}_{2}\right] /\left[\operatorname{Red}_{1}\right]\right)}\right\} \quad(\mathrm{mV}),
$$

The relationship between $\Delta E$ and $\left[\mathrm{Ox}_{2}\right]$ depends on both the initial concentration ratio of $\mathrm{Ox}_{1}$ to $\operatorname{Red}_{1}$ and the value of $n$, which can be estimated from (4). The variation in $\Delta E$ with $\left[\mathrm{Ox}_{2}\right]$, under the condition that the value of $n$ is 1 , becomes linear within ca. $40 \mathrm{mV}$, when the value of $\left[\mathrm{Ox}_{1}\right] /\left[\mathrm{Red}_{1}\right]$ is about 0.5 . When $\left[\mathrm{Ox}_{1}\right] /\left[\operatorname{Red}_{1}\right]$ is higher than 2 or lower than 0.2 , the sensitivity, slope of the calibration curve, increases, but the shapes of the curves become concave or convex, respectively. Thus, the potential change and baseline potential of the redox electrode are governed by the change in the composition of the redox couple in the potential buffer solution, according to (4). The linear relationship can be utilized as a calibration curve for an $\mathrm{Ox}_{2}$ sample. However, the upper limit for the measurable concentration of the $\mathrm{Ox}_{2}$ with linearity is limited by the concentration of the potential buffer, as predicted from (4). This limitation means that the concentration of the potential buffer should be chosen in accordance with the concentration of the analyte. In other words, the measurable concentration level of the $\mathrm{Ox}_{2}$ can be altered by choosing the concentrations of the potential buffer.

When an $\mathrm{Fe}(\mathrm{III})-\mathrm{Fe}(\mathrm{II})$ couple in a sulfuric acid solution is used as the redox couple, $\mathrm{Ox}_{1}-\mathrm{Red}_{1}$ (1) can be replaced with the following equation:

$$
\mathrm{Ox}+m \mathrm{Fe}^{2+}+a \mathrm{H}^{+} \longrightarrow \mathrm{Red}+m \mathrm{Fe}^{3+}+b \mathrm{H}_{2} \mathrm{O}
$$

where $m$ is the number of moles of $\mathrm{Fe}^{2+}$ required to reduce $1 \mathrm{~mol}$ of an analyte, $\mathrm{Ox}$, and $a$ and $b$ are stoichiometric coefficients. If reaction (5) is complete, the potential change $(\Delta E)$ of the redox electrode at $25^{\circ} \mathrm{C}$ can be expressed by (6) in the same as (4)

$$
\Delta E=59 \log \left\{\frac{\left(1+m[\mathrm{Ox}]_{0} /\left[\mathrm{Fe}^{3+}\right]_{0}\right)}{\left(1-m[\mathrm{Ox}]_{0} /\left[\mathrm{Fe}^{2+}\right]_{0}\right)}\right\} \quad(\mathrm{mV}),
$$

where $[\mathrm{Ox}]_{0},\left[\mathrm{Fe}^{3+}\right]_{0}$, and $\left[\mathrm{Fe}^{2+}\right]_{0}$ are the initial concentrations of $\mathrm{Ox}, \mathrm{Fe}^{3+}$, and $\mathrm{Fe}^{2+}$, respectively. In the case of completion of reaction (5), the variation in $\Delta E$ with [Ox] becomes relatively linear in the concentration range of $\mathrm{Ox}$, where the $\Delta E$ is within $c a .20 \mathrm{mV}$, when the value of $\left[\mathrm{Fe}^{3+}\right]_{0} /\left[\mathrm{Fe}^{2+}\right]_{0}$ is nearly equal to unity. The theoretical sensitivities, defined as the slope of the linear portion of the $\Delta E$ versus $[\mathrm{Ox}]$ plot, are calculated to be $10.4,20.9$, and $31.3 \mathrm{mV} \mathrm{mM}^{-1}$ for $m=2,4$, and 6, respectively, from (6), when the concentration of $\left[\mathrm{Fe}^{3+}\right]_{0}$ and $\left[\mathrm{Fe}^{2+}\right]_{0}$, respectively, is equal to $0.01 \mathrm{M}$. These calculated values for sensitivity to several oxidative species are given in Table 3 .

In practice, the potential change, $\Delta E$, is influenced, not only by the concentration of the sample but also by

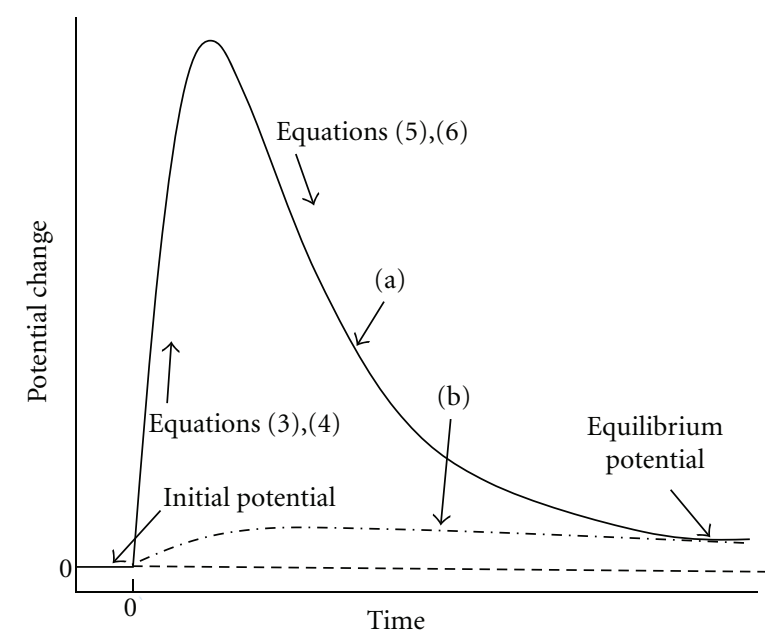

FIgURe 2: Potential changes during the reaction of Ox with an $\mathrm{Fe}$ (III)-Fe(II) buffer solution containing bromide or chloride (a) and without bromide or chloride (b) as a function of time.

the dispersion of the sample zone in the flow system. However, one of the advantages of FIA is that it is capable of precisely controlling the dispersion of the flow condition. Hence, the peak height would be expected to be proportional to the concentration of sample.

The theoretical potential change for a reductive sample can be predicted by changing the signs in front of $m$ of (4) opposite.

\subsection{Transient Potential Change of a Redox Electrode due} to Intermediate Generated during Complex Redox Reaction with $\mathrm{Fe}(I I I)-\mathrm{Fe}(\mathrm{II})$ Potential Buffer Containing Bromide or Chloride. Figure 2 shows the typical potential responses of the redox electrode arising in which Ox sample is added to an $\mathrm{Fe}(\mathrm{III})-\mathrm{Fe}(\mathrm{II})$ potential buffer without bromide or chloride or containing bromide or chloride in the batchwise experiments. In the case that an $\mathrm{Fe}$ (III)-Fe(II) potential buffer without bromide or chloride is used, the response potential increase gradually with time and finally reaches a constant equilibrium potential, as shown in Figure 2(b). The potential change between the initial potential and the equilibrium potential agrees well with the value calculated from (6). On the other hand, in the case that an $\mathrm{Fe}$ (III)-Fe(II) potential buffer containing bromide or chloride is used, the response potential with a mountain-shaped transient change appears with increasing reaction time, as shown in Figure 2(a), although the concentration of $\mathrm{Ox}$ is lower by about three orders magnitude than that in the potential buffer. The potential increases quickly, decreases with time after passing through a maximum, and finally reaches a constant equilibrium potential which is almost the same as that of Figure 2(b). The transient potential change is due to the generation of bromine or chlorine as an intermediate formed by the reaction of $\mathrm{Ox}$ with bromide or chloride in the potential buffer.

The mechanism of the transient change in potential shown in Figure 2(a) can be explained qualitatively by 
TABLE 1: Determination of ethanol content in alcoholic beverages.

\begin{tabular}{lcccc}
\hline & & \multicolumn{2}{c}{ Ethanol content, \% (v/v) } & \\
Certified value & Specific gravity method & GC method & FIA method (without G.D.) & Proposed method (G.D.) \\
\hline Beer ${ }^{2}$ 4.5 & 4.5 & 4.3 & 6.6 & 4.4 \\
Wine $<14$ & & 11.5 & 16.5 & 11.5 \\
Sake 16-17 & \multirow{2}{*}{16.8} & 16.0 & 19.5 & 16.1 \\
Whisky 43 & & 42.5 & 42.6 & 42.6 \\
Shochu 25 & & 24.5 & 24.6 & 25.0 \\
\hline
\end{tabular}

${ }^{\mathrm{a}}$ The sample was debubbled for $20 \mathrm{~min}$ before analysis.

TABle 2: Effect of concentrations of $\mathrm{Fe}(\mathrm{CN})_{6}{ }^{3-}-\mathrm{Fe}(\mathrm{CN})_{6}{ }^{4-}$ potential buffer solution on sensitivity.

\begin{tabular}{lcc}
\hline $\begin{array}{l}\text { Concentration } \\
(\mathrm{M})\end{array}$ & $\begin{array}{c}\text { Sensitivity } \\
\left(\mathrm{mV} \mathrm{mM}^{-1}\right)\end{array}$ & $\begin{array}{c}\text { Measurable concentration } \\
\text { range }(\mathrm{M})\end{array}$ \\
\hline $1 \times 10^{-2}$ & 9.7 & $2.0 \times 10^{-4} \sim 1.8 \times 10^{-3}$ \\
$1 \times 10^{-3}$ & $9.5 \times 10$ & $2.0 \times 10^{-5} \sim 1.8 \times 10^{-4}$ \\
$1 \times 10^{-4}$ & $9.4 \times 10^{2}$ & $2.0 \times 10^{-6} \sim 1.8 \times 10^{-5}$ \\
$5 \times 10^{-5}$ & $1.9 \times 10^{3}$ & $1.0 \times 10^{-6} \sim 1.0 \times 10^{-5}$ \\
$1 \times 10^{-5}$ & $6.2 \times 10^{3}$ & $2.5 \times 10^{-7} \sim 2.5 \times 10^{-6}$ \\
\hline
\end{tabular}

${ }^{\mathrm{a}}$ Sensitivity: slope of calibration curve (peak height/mV obtained by injection of $1 \mathrm{mM}$ glucose).

Table 3: Sensitivities to oxidative species.

\begin{tabular}{lccc}
\hline $\begin{array}{l}\text { Oxidative } \\
\text { species }\end{array}$ & \multicolumn{2}{c}{$\begin{array}{c}\text { Sensitivity }(\mathrm{mv} / \mathrm{mM})^{\mathrm{b}} \\
\text { (A) Observed in } \\
\text { FIA system }\end{array}$} & $\begin{array}{c}\text { Enhancement } \\
\text { factor, }(\mathrm{A}) /(\mathrm{B})\end{array}$ \\
\hline $\mathrm{BrO}_{3}{ }^{-}$ & $10.6 \times 10^{3}$ & $31.3(m=6)$ & 338 \\
$\mathrm{Cr}_{2} \mathrm{O}_{7}{ }^{2-}$ & $2.6 \times 10^{3}$ & $31.3(m=6)$ & 83 \\
$\mathrm{H}_{2} \mathrm{O}_{2}$ & $2.5 \times 10^{2 \mathrm{c}}$ & $10.4(m=2)$ & 24 \\
$\mathrm{ClO}_{2}{ }^{-}$ & $6.9 \times 10^{3}$ & $20.9(m=4)$ & 339 \\
$\mathrm{O}_{3}$ & $8.0 \times 10^{2}$ & $10.4(m=2)$ & 77 \\
\hline
\end{tabular}

${ }^{a}$ Sensitivity calculated from (6).

${ }^{b}$ Buffer, consisting of $0.01 \mathrm{M} \mathrm{Fe}(\mathrm{III})-0.01 \mathrm{M} \mathrm{Fe}(\mathrm{II})$ containing $0.4 \mathrm{M} \mathrm{NaBr}$ and $1.2 \mathrm{M} \mathrm{H}_{2} \mathrm{SO}_{4}$, was used as the reagent solution.

${ }^{\mathrm{c}}$ Buffer containing $0.5 \%$ ammonium molybdate to above buffer was used.

considering the following reactions: Ox reacts first with bromide or chloride in the potential buffer, and the reaction generates bromine or chlorine as an intermediate during the course of the reaction. Second, the intermediate $\left(\mathrm{Br}_{2}\right.$ or $\mathrm{Cl}_{2}$ ) reacts with $\mathrm{Fe}(\mathrm{II})$ in the potential buffer. Thus, these reactions can be expressed by the following:

$$
\begin{gathered}
\mathrm{Ox}+a \mathrm{Br}^{-}+b \mathrm{H}^{+} \longrightarrow \mathrm{Red}+\frac{a}{2} \mathrm{Br}_{2}+c \mathrm{H}_{2} \mathrm{O} \\
\mathrm{Ox}+a \mathrm{Cl}^{-}+b \mathrm{H}^{+} \longrightarrow \mathrm{Red}+\frac{a}{2} \mathrm{Cl}_{2}+c \mathrm{H}_{2} \mathrm{O} \\
\frac{a}{2} \mathrm{Br}_{2}+\mathrm{Fe}^{2+} \longrightarrow a \mathrm{Br}^{-}+\mathrm{Fe}^{3+} \\
\frac{a}{2} \mathrm{Cl}_{2}+\mathrm{Fe}^{2+} \longrightarrow a \mathrm{Cl}^{-}+\mathrm{Fe}^{3+}
\end{gathered}
$$

where Red is the reduced form of Ox. For the mountainshaped transient change, the initial potential is governed by the $\mathrm{Fe}(\mathrm{III})-\mathrm{Fe}(\mathrm{II})$ ratio in the potential buffer. When Ox is added to the potential buffer, since $\mathrm{Br}_{2}$ or $\mathrm{Cl}_{2}$ is generated by (7) or (8), the electrode potential is shifted from $\mathrm{Fe}$ (III)/Fe(II) to $\mathrm{Br}_{2} / \mathrm{Br}^{-}$or $\mathrm{Cl}_{2} / \mathrm{Cl}^{-}$. Since the redox potential of the $\mathrm{Br}_{2} / \mathrm{Br}^{-}$couple $\left(E_{0}=1.09 \mathrm{~V}\right)$ or the $\mathrm{Cl}_{2} / \mathrm{Cl}^{-}$ couple $\left(E_{0}=1.33 \mathrm{~V}\right)$ is much higher than that of the $\mathrm{Fe}(\mathrm{III}) / \mathrm{Fe}(\mathrm{II})$ redox couple $\left(E_{0}=0.77 \mathrm{~V}\right)$, the electrode potential increases towards a positive potential due to (7) or (8). The potential then decreases towards an equilibrium potential due to (9) or (10). The overall reaction which is the sum of elementary reactions (7) and (9) or of reactions (8) and (10) is given by (5) in equilibrium potential. That is, bromide or chloride in the potential buffer may act as a homogeneous catalyst for the formation and reduction of bromine or chlorine. The magnitude of the large transient potential change increases with decreasing concentration of $\mathrm{Fe}(\mathrm{III})-\mathrm{Fe}(\mathrm{II})$ in the potential buffer components. This is due to the fact that the rate of reduction of bromine or chlorine by $\mathrm{Fe}(\mathrm{II})$ expressed by (9) or (10), respectively, decreases. In addition, since reactions (7) and (9) or (8) and (10) proceed successively, the amount of bromine or chlorine generated as an intermediate is calculated to be proportional to the initial concentration of $\mathrm{Ox}$ at anytime of reaction period, if the generation rate of bromine or chlorine is governed by the first-order reaction in terms of the concentration of $\mathrm{Ox}$ and depletion rate of bromine or chlorine is also governed by the first-order reaction in terms of bromine or chlorine. Therefore the linear calibration between the potential change $\Delta E$ and the concentration of $\mathrm{Ox}$ is expected.

In the FIA system, the reaction time for the reaction of a sample with a reagent can be easily controlled by using different coil lengths and/or different flow rates for the carrier and reagent streams. The concentrations of sulfuric acid, bromide or chloride, and $\mathrm{Fe}(\mathrm{III})-\mathrm{Fe}(\mathrm{II})$ in the potential buffer solution are also important factors in terms of enhancing sensitivity. By determining these optimum analytical conditions for the highly sensitive determination of oxidative species, a two-channel flow system, carrier stream $\left(\mathrm{H}_{2} \mathrm{O}\right)$ and reagent stream $\left(\mathrm{Fe}^{3+}-\mathrm{Fe}^{2+}, \mathrm{NaBr}\right.$, or $\mathrm{NaCl}$ in $\mathrm{H}_{2} \mathrm{SO}_{4}$ solution), was designed to detect the large transient potential change within a reasonable time, where the maximum appears transiently. The flow-injection apparatus was the same as that shown in Figure 1. The potential changes (peak signals) measured at appropriate reaction times were proportional to the concentration of oxidative species. 


\section{Analyses Utilizing an Equilibrium Potential after Completion of a Simple Redox Reaction}

5.1. Analyses of Concentrated Hydrogen Peroxide and Ethanol in Alcoholic Beverages Using $\mathrm{Fe}(\mathrm{III})-\mathrm{Fe}(\mathrm{II})$ Potential Buffer [17-19]. Concentrated hydrogen peroxide is used in the breaching of pulp and textiles and for washing silicon wafers. For process control in the production of hydrogen peroxide in the pulp and semiconductor industries, the determination of concentrated hydrogen peroxide is routinely carried out by titrimetry after a moderate sample dilution procedure. However, a more rapid method for the determination of concentrated hydrogen peroxide would be desirable, because titrimetry is tedious and time-consuming. The determination of hydrogen peroxide was proposed by using the Fe(III)$\mathrm{Fe}$ (II) couple in an acidic solution as the potential buffer solution, according to

$$
\mathrm{H}_{2} \mathrm{O}_{2}+2 \mathrm{Fe}^{2+}+2 \mathrm{H}^{+} \longrightarrow 2 \mathrm{Fe}^{3+}+2 \mathrm{H}_{2} \mathrm{O}
$$

In the flow system, an analyte at high concentration can be determined by utilizing the controlled dispersion of the sample zone, and its dispersion depends on the sample volume and coil length (residence time) from the injector to the detector. In this method [17], which does not require any sample dilution, the determination of hydrogen peroxide in concentrations of up to $\sim 10 \mathrm{M}(30 \%)$ was successfully achieved using a $0.4 \mathrm{M} \mathrm{Fe}(\mathrm{III})-0.4 \mathrm{M}$ Fe(II) potential buffer containing $1 \mathrm{M} \mathrm{H}_{2} \mathrm{SO}_{4}$, where the sample could be diluted by $c a .80$-fold by injecting a very small volume to $1 \mu \mathrm{L}$ and by setting the residence time of the sample zone to $1 \mathrm{~min}$, as a standard procedure in flow system. Even in such a high dispersion system, the R.S.D for the determination of $9.86 \mathrm{M}$ $\mathrm{H}_{2} \mathrm{O}_{2}$ was $0.7 \%(n=10)$. A sampling rate of $\sim 30 \mathrm{~h}^{-1}$ was possible at the present flow condition. The proposed method could be used in the online monitoring of the production of hydrogen peroxide, as well as for bleaching and washing processes which use concentrated hydrogen peroxide.

An accurate and selective determination method for the ethanol content in alcoholic beverages usually involves the use of a gas chromatographic technique or a specific-gravity method (currently, the official method in Japan). However, a simpler, rapid, and selective method is possible using a flow-injection technique, in which the alcohol is separated using a porous membrane. In this method, the selective determination method of ethanol in alcoholic beverages (Japanese sake, beer, wine, whisky, and shochu) was proposed, using the $\mathrm{Fe}$ (III)-Fe(II) potential buffer solution and a gas-diffusion unit equipped with a membrane [19]. The flow injection manifold, equipped for gas-diffusion separation is shown in Figure 3. The gas-diffusion separation unit (G.D.) is comprised of two Daiflon blocks furnished with a shallow groove ( $37 \mathrm{~mm}$ long, $3 \mathrm{~mm}$ wide, $0.5 \mathrm{~mm}$ deep) and separated by a porous poly (tetrafluoroethylene) (PTFE) plane membrane, which allows the transfer of ethanol from a stream of C.S. to a stream of R.S.. . The PTFE membrane is $50 \mu \mathrm{m}$ thick, with a pore size of $0.4 \mu \mathrm{m}$. The method is based on the detection of the composition change of the Fe(III)$\mathrm{Fe}$ (II) couple in the potential buffer, caused by the reduction of acidic dichromate by ethanol that had permeated through a membrane as vapor, according to

$$
\begin{gathered}
3 \mathrm{C}_{2} \mathrm{H}_{5} \mathrm{OH}+2 \mathrm{Cr}_{2} \mathrm{O}_{7}^{2-}+16 \mathrm{H}^{+} \\
\longrightarrow 3 \mathrm{CH}_{3} \mathrm{COOH}+4 \mathrm{Cr}^{3+}+11 \mathrm{H}_{2} \mathrm{O} \\
\mathrm{Cr}_{2} \mathrm{O}_{7}^{2-}+6 \mathrm{Fe}^{2+}+14 \mathrm{H}^{+} \longrightarrow 2 \mathrm{Cr}^{3+}+6 \mathrm{Fe}^{3+}+7 \mathrm{H}_{2} \mathrm{O}
\end{gathered}
$$

The PTFE membrane for the separation of alcohol was superior to a poly(substituted-acetylene)/polysiloxane graft copolymer membrane [18], because of the high permeability of alcohol and the simplicity of the manifold. The flow injection peaks for a calibration curve were obtained in the ethanol concentration range from 5 to $40 \%(\mathrm{v} / \mathrm{v})$ using the flow condition indicated in Figure 3. Sampling rate was $\sim 25 \mathrm{~h}^{-1}$. The analytical results for the ethanol content in alcoholic beverages determined by the proposed method were in good agreement with data obtained by either the specific-gravity method or a gas chromatographic method, as shown in Table 1. The R.S.D for the proposed method was smaller than those by the other methods.

Incidentally, when the FIA technique was employed without using the G.D., positive errors of $20-30 \%$ were observed for Japanese sake, beer, and wine, which also contain compounds such as sugars, organic acids, and amino acids, which are also oxidized by the dichromate solution.

5.2. Analyses of Reducing Sugars, Amylase, and Manganese(II) Using an $\mathrm{Fe}(\mathrm{CN})_{6}{ }^{3-}-\mathrm{Fe}(\mathrm{CN})_{6}{ }^{4-}$ Potential Buffer [20-25]. The redox couple $\mathrm{Fe}(\mathrm{CN})_{6}{ }^{3-}-\mathrm{Fe}(\mathrm{CN})_{6}{ }^{4-}$ has a lower redox potential of $0.36 \mathrm{~V}$ and is known to show unique redox behavior in the presence of reducing sugars. The redox electrode shows a stable potential to the $\mathrm{Fe}(\mathrm{CN})_{6}{ }^{3-}-\mathrm{Fe}(\mathrm{CN})_{6}{ }^{4-}$ couple in alkaline media, but is not stable in neutral to acidic solution because the auto-oxidation of $\mathrm{Fe}(\mathrm{CN})_{6}{ }^{4-}$ to $\mathrm{Fe}(\mathrm{CN})_{6}{ }^{3-}$ occurs in such media. The redox electrode also showed a Nernstian response even at lower concentrations of $\mathrm{Fe}(\mathrm{CN})_{6}{ }^{3-}-\mathrm{Fe}(\mathrm{CN})_{6}{ }^{4-}$ potential buffer down to $10^{-5} \mathrm{M}$ in alkaline media. Thus, it would be expected that system could be used in the sensitive determination of certain compounds and could also be used in a wide concentration range of analytes, as described above.

For an example of an analysis utilizing a change in the composition of the $\mathrm{Fe}(\mathrm{CN})_{6}{ }^{3-}-\mathrm{Fe}(\mathrm{CN})_{6}{ }^{4-}$ potential buffer, an analytical method for reducing sugars [20] was proposed based on the reaction of a reducing sugar with of $\mathrm{Fe}(\mathrm{CN})_{6}{ }^{3-}$ in alkaline solution, according to

$$
\begin{aligned}
& \text { Reducing sugar }+m \mathrm{Fe}(\mathrm{CN})_{6}{ }^{3-} \\
& \longrightarrow m \mathrm{Fe}(\mathrm{CN})_{6}{ }^{4-}+\text { other products }
\end{aligned}
$$

where $m$ is the number of moles required to oxidize one mole of reducing sugar.

In the case for the determination of glucose [21], the concentration of $\mathrm{NaOH}$ in the potential buffer and the temperature of the reaction, as a standard procedure in flow system shown in Figure 1, were $0.6 \mathrm{M}$ and $85^{\circ} \mathrm{C}$, respectively. 


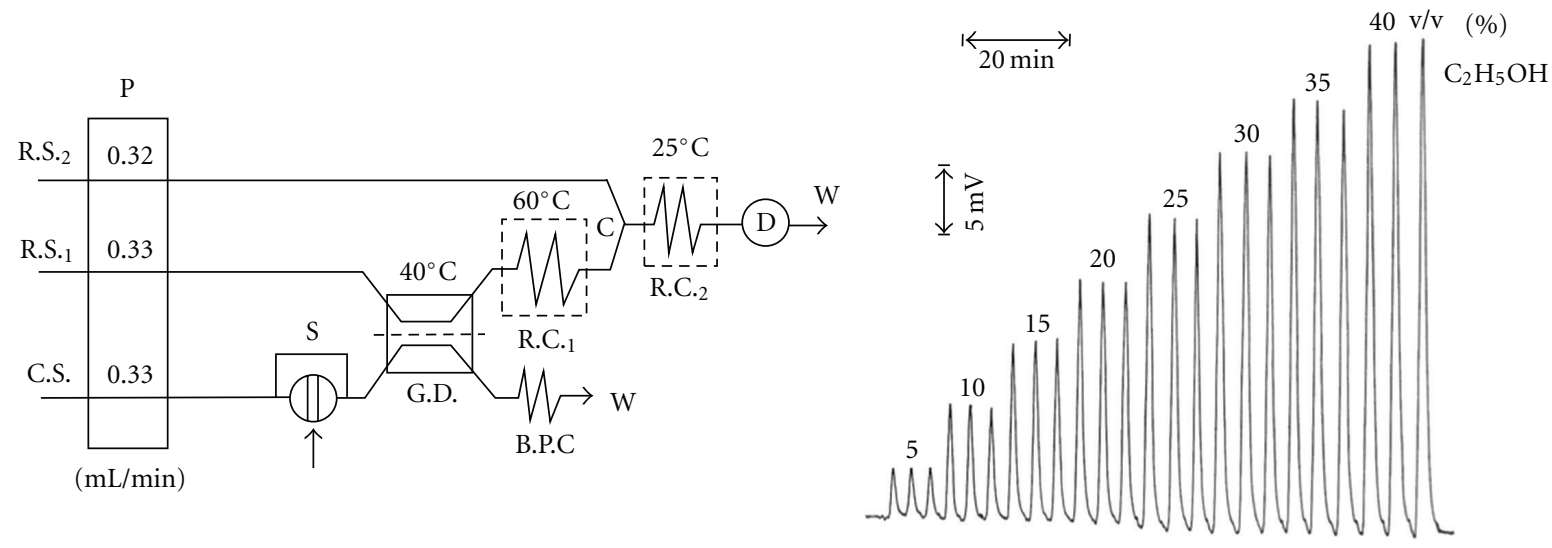

FIGURE 3: Flow-injection manifold equipped with a gas-diffusion separation unit for the determination of ethanol and calibration peaks for ethanol. C.S: carrier $\left(\mathrm{H}_{2} \mathrm{O}\right)$ : R.S. . $_{\text {: }}$ reagent solution $\left(0.015 \mathrm{M} \mathrm{K}_{2} \mathrm{Cr}_{2} \mathrm{O}_{7}, 2 \mathrm{M} \mathrm{H}_{2} \mathrm{SO}_{4}\right)$; R.S.2. reagent solution $\left(0.135 \mathrm{M} \mathrm{Fe}\left(\mathrm{NH}_{4}\right)_{2} \mathrm{SO}_{4}\right)$; $\mathrm{S}$ : sample injector $(140 \mu \mathrm{L})$; G.D: gas-diffusion separation unit; R.C. 1 : reaction coil $(1 \mathrm{~m}, 0.5 \mathrm{~mm})$; R.C. 2 : reaction coil $(2 \mathrm{~m}, 0.5 \mathrm{~mm})$; B.P.C: back pressure coil $(10 \mathrm{~m}, 0.5 \mathrm{~mm})$.

These conditions were selected for showing the highest sensitivity by changing the $\mathrm{NaOH}$ concentration from $0.01 \mathrm{M}$ to $1.0 \mathrm{M}$ and the temperature from $50^{\circ} \mathrm{C}$ to $90^{\circ} \mathrm{C}$. The time required for a reaction between glucose and $\mathrm{Fe}(\mathrm{CN})_{6}{ }^{3-}$ to be completed is about $2.5 \mathrm{~min}$ and $m$ values of $\mathrm{Fe}(\mathrm{CN})_{6}{ }^{3-}$ for the oxidation of $1 \mathrm{~mol}$ glucose was 6 , as calculated from response potential $(\Delta E)$ after completion of the reaction. The total time required was about $4.2 \mathrm{~min}$ from sample injection $(140 \mu \mathrm{L})$ to the detection of a peak maximum in the flow system. FIA peaks for injections at 2 min intervals were reproducible, and, as a result, it is possible to analyze 30 samples $/ \mathrm{h}$ using the proposed procedure. Table 2 lists the sensitivity values and measurable concentration ranges for various concentrations of buffer solutions. The sensitivity increased with decreasing concentration of buffer solution. A sample in the concentration range from $10^{-7} \mathrm{M}$ to $10^{-3} \mathrm{M}$ could be determined by changing the concentration of the $\mathrm{Fe}(\mathrm{CN})_{6}{ }^{3-}$ $\mathrm{Fe}(\mathrm{CN})_{6}{ }^{4-}$ potential buffer solution from $1 \times 10^{-5} \mathrm{M}$ to $1 \times$ $10^{-2} \mathrm{M}$. For the $1 \times 10^{-5} \mathrm{M} \mathrm{Fe}(\mathrm{CN})_{6}{ }^{3-}-\mathrm{Fe}(\mathrm{CN})_{6}{ }^{4-}$ potential buffer, the fluctuations and drifts in the baseline potential were within $0.3 \mathrm{mV}$ and less than $0.8 \mathrm{mV} / \mathrm{h}$, respectively, and the lowest detectable concentration was $0.1 \mu \mathrm{M}$ (peak heights: $0.6 \mathrm{mV}$ ). When the concentration of the potential buffer was lower than $5 \times 10^{-6} \mathrm{M}$, the drift and fluctuation of the baseline potential became larger, and peak heights were not reproducible. The high sensitivity of the proposed FIA method can be attributed to, in part, the high stability of the electrode potentials in buffer solutions at low concentrations.

Other reducing sugars, in addition to glucose (2deoxy-D-ribose, L-rhamnose, D-ribose, and D-mannose as monosaccharides, and cellobiose, maltose, and lactose as disaccharides), were also determined by the same proposed FA method [20]. The sensitivity of the disaccharides was higher by about 1.5 -fold than that of monosaccharides, although there are somewhat sensitivity differences among disaccharides and monosaccharides. The reason for difference in sensitivity between monosaccharides and disaccharides is not clear at this stage.
The separate determination of mixtures of reducing sugars was achieved by combining proposed FIA method with HPLC as a postcolumn technique [22]. In this case, the sugars were converted to borate complexes by dissolving them in a borate solution, which was used as an eluent, followed by separation on an anion-exchange column. The lower detection limit of reducing sugars was as low as 0.4$2.0 \mu \mathrm{M}$ for an injection of $20 \mu \mathrm{L}$ sample. The sensitivity of the proposed potentiometric method is similar or higher than corresponding values for amperometric, fluorometric, and spectrophotometric detection methods. Furthermore, it was possible to simultaneously determine sucrose and glucose using the proposed FIA method, by incorporating a bypass coil connected with invertase-immobilized column in parallel [23].

As an application for the determination of reducing sugars, the determination of amylase activity [24] was carried out by utilizing the redox reaction of $\mathrm{Fe}(\mathrm{CN})_{6}{ }^{3-}$ with reducing sugars, produced by the enzymatic hydrolysis $\left(37^{\circ} \mathrm{C}\right)$ of starch with amylase. The flow system consisted of three streams, a carrier stream of water, a stream of $10 \mathrm{mM}$ soluble-starch (pH: 5.0), and a stream of an $\mathrm{Fe}(\mathrm{CN})_{6}{ }^{3-}-\mathrm{Fe}(\mathrm{CN})_{6}{ }^{4-}$ potential buffer solution. It was possible to determine $15 \mathrm{samples} / \mathrm{h}$ with good reproducibility, although about $6 \mathrm{~min}$ from sample injection to the detection of a peak maximum in the flow system was required. Amylase in a wide activity concentration range $\left(10^{-2} \mathrm{U} \mathrm{mL}^{-1}-10^{-4} \mathrm{U} \mathrm{mL}^{-1}\right)$ could be determined by appropriate selection of the concentration of the potential buffer $\left(10^{-3} \mathrm{M}-10^{-5} \mathrm{M}\right)$. The proposed FIA method was applied to the determination of amylase in digestive medicines from five pharmaceutical companies. The analytical results obtained using the proposed method were in good agreement with those obtained using the official titrimetric method (modified Somogyi method) within relative errors of 4.5-8.7\%. No significant interference was observed in the digestive medicines examined in this study. 
The determination of metal ions such as manganese(II) and cobalt(II) was found to be possible using the same $\mathrm{Fe}(\mathrm{CN})_{6}{ }^{3-}-\mathrm{Fe}(\mathrm{CN})_{6}{ }^{4-}$ potential buffer as was used for reducing sugars [25]. The flow system of the proposed FIA method consisted of two-channel streams, a water and the $\mathrm{Fe}(\mathrm{CN})_{6}{ }^{3-}-\mathrm{Fe}(\mathrm{CN})_{6}{ }^{4-}$ potential buffer $(\mathrm{pH}: 8.0)$ containing $0.2 \mathrm{M}$ ammonium citrate and $0.01 \mathrm{M} \mathrm{NaOH}$. The addition of ammonium citrate to the potential buffer in alkaline media accelerated the reaction of manganese(II) or cobalt(II) with $\mathrm{Fe}(\mathrm{CN})_{6}{ }^{3-}$. However, the reactivity of $\mathrm{Fe}(\mathrm{CN})_{6}{ }^{3-}$ with manganese(II) and cobalt(II), respectively, was quite different in various $\mathrm{pH}$ media and that of $\mathrm{Fe}(\mathrm{CN})_{6}{ }^{3-}$ with manganese(II) was much higher than that with cobalt(II). Hence, the selective determination of manganese(II), even in the presence of cobalt(II), the concentration of which was 50-fold that of $\mathrm{Mn}(\mathrm{II})$, was possible by selecting reaction conditions near $\mathrm{pH}$ 8. During our studies of the effects of several metal ions on the determination of manganese(II) by the proposed FIA method, the tolerated concentrations of coexisting metal ions for the determination of $3 \times 10^{-6} \mathrm{M}$ $\mathrm{Mn}(\mathrm{II})$ were determined to be $3 \times 10^{-3} \mathrm{M}$ for $\mathrm{Ca}(\mathrm{II}), \mathrm{Mg}$ (II), and $\mathrm{Ni}(\mathrm{II}), 1.5 \times 10^{-3} \mathrm{M}$ for $\mathrm{Cu}(\mathrm{II}), \mathrm{Zn}(\mathrm{II})$, and $\mathrm{Al}(\mathrm{III})$, and $3 \times 10^{-4} \mathrm{M}$ for $\mathrm{Cr}$ (III) and $\mathrm{Fe}(\mathrm{III})$. The lower detection limit for manganese(II) was $1 \times 10^{-7} \mathrm{M}$, and the proposed method provided almost the same sensitivity compared with the other flow injection technique. Manganese(II) in soils is known to be one of essential components for plant growth. The proposed method was applied to the determination of manganese(II) levels in four soil samples obtained from a tea field. The analytical results obtained by the proposed method were in good agreement with those obtained using atomic absorption spectrometry. The contents $\left(\mathrm{mg} \mathrm{g}^{-1}\right.$ soil) of the main coexisting metals in the soil samples were magnesium (ca. 15), calcium (ca. 14), aluminum (ca. 145), and iron (ca. 45), as determined by inductively coupled plasma spectrophotometry. Thus, the proposed method would be useful for monitoring manganese(II) in environmental samples, such as sea water and raw water, judging from the concentration of various coexisting metal ions that can be tolerated.

5.3. Analysis of Phenol Using a Bromine-Bromide Potential Buffer and a Combined Platinum Electrode with Bromide IonElectrode $[26,27]$. The analysis of phenols in the presence of other organic compounds can be typically achieved by titrimetry utilizing bromination reactions. In this proposed method, phenol is determined via a bromination reaction with a bromine-bromide potential buffer solution in the stream, where a combined electrode detector consisting of a platinum electrode and a bromide-selective electrode instead of the silver/silver chloride reference electrode shown in Figure 1 was used for detecting the change in bromine concentration [26]. The bromination reaction is expressed by

$$
\mathrm{C}_{6} \mathrm{H}_{5} \mathrm{OH}+3 \mathrm{Br}_{2} \longrightarrow \mathrm{C}_{6} \mathrm{H}_{2} \mathrm{Br}_{3} \mathrm{OH}+3 \mathrm{HBr}
$$

When the bromination reaction reaches completion, according to (15), the potential change $(\Delta E)$ of the combined electrode is expressed as follows from Nernstian equations for both electrodes:

$$
\Delta E=29.5 \log \left\{\frac{\left(\left[\mathrm{Br}_{2}\right]_{0}-3\left[\mathrm{C}_{6} \mathrm{H}_{5} \mathrm{OH}\right]_{0}\right)}{\left[\mathrm{Br}_{2}\right]_{0}}\right\} \quad(\mathrm{mV})
$$

where $\left[\mathrm{Br}_{2}\right]_{0}$ and $\left[\mathrm{C}_{6} \mathrm{H}_{5} \mathrm{OH}\right]_{0}$ are the initial concentrations of bromine and phenol, respectively. The theoretical calibration curve (i.e., the case of a complete reaction) calculated from (16) became concave. However, assuming a second-order reaction on a transient reaction between phenol and bromine in a large excess of sulfuric acid, the relationship between $\Delta E$ and $\left[\mathrm{C}_{6} \mathrm{H}_{5} \mathrm{OH}\right]_{0}$ is approximately linear, when the amount of bromine reacted is smaller than ca. $38 \%$ against the initial concentration of bromine. Thus, the analysis was conducted by utilizing the detection of the transient potential change in the initial stage of the bromination of phenol in a flow system. As the standard conditions in the flow system, when the reagent solution (R.S.) was used $1.5 \times 10^{-5} \mathrm{M} \mathrm{Br}_{2}-0.4 \mathrm{M} \mathrm{Br}^{-}$containing $0.2 \mathrm{M}$ $\mathrm{H}_{2} \mathrm{SO}_{4}$, a linear relationship between peak signals and phenol concentration can be seen in the range of $5 \times 10^{-6} \mathrm{M}$ to $2.5 \times 10^{-5} \mathrm{M}$. Incidentally, the transient reaction in (15) was confirmed to be a second-order reaction by stopped-flow spectrophotometry [26].

The proposed method can also be used for the determination of other phenols, including $p$-nitrophenol, $p$ chlorophenol, $\beta$-naphthol, and $m$-cresol and was further applied to the separate determination of phenols by combining the proposed FIA method with HPLC, as a postcolumn technique [27].

\section{Analyses Utilizing a Large Transient Potential Change Caused by a Complex Redox Reaction}

6.1. Analysis of Bromate Using $\mathrm{Fe}(I I I)-\mathrm{Fe}(I I)$ Potential Buffer Containing Bromide [28-30]. Bromate is employed as bleaching agent for some food products and is known to be generated as a byproduct in water purification processes. Thus, the sensitive determination of residual bromate in foods or tap water would be desirable for the safety of food products and water quality. In a batchwise experiment [28], the time course for the response potential after the addition of bromate to a potential buffer consisting of $\mathrm{Fe}$ (III)-Fe(II) containing bromide showed a mountain-shaped form, as shown in Figure 2. The large transient potential process which is due to bromine, generated as an intermediate, can be expressed by the following reactions, as described in Section 4.2:

$$
\begin{gathered}
\mathrm{BrO}_{3}^{-}+5 \mathrm{Br}^{-}+6 \mathrm{H}^{+} \longrightarrow 3 \mathrm{Br}_{2}+3 \mathrm{H}_{2} \mathrm{O} \\
\mathrm{BrO}_{3}^{-}+5 \mathrm{Fe}^{2+}+6 \mathrm{H}^{+} \longrightarrow \frac{1}{2} \mathrm{Br}_{2}+5 \mathrm{Fe}^{3+}+3 \mathrm{H}_{2} \mathrm{O} \\
\frac{1}{2} \mathrm{Br}_{2}+\mathrm{Fe}^{2+} \longrightarrow \mathrm{Br}^{-}+\mathrm{Fe}^{3+}
\end{gathered}
$$




$$
\begin{gathered}
\mathrm{BrO}_{3}{ }^{-}+6 \mathrm{Fe}^{2+}+6 \mathrm{H}^{+} \longrightarrow \mathrm{Br}^{-}+6 \mathrm{Fe}^{3+}+3 \mathrm{H}_{2} \mathrm{O} \\
\Delta E=59 \log \left\{\frac{\left(1+6\left[\mathrm{BrO}_{3}^{-}\right]_{0} /\left[\mathrm{Fe}^{3+}\right]_{0}\right)}{\left(1-6\left[\mathrm{BrO}_{3}^{-}\right]_{0} /\left[\mathrm{Fe}^{2+}\right]_{0}\right)}\right\} .
\end{gathered}
$$

The overall reaction, which is the sum of elementary reactions (17), (18), and (19), is given by (20). The equilibrium potential, normalized by the concentration of bromate, as observed from the time course agreed well with the value $(31.3 \mathrm{mV} / \mathrm{mM}$, Table 2) calculated from (2). In a transient potential, the maximum change of $20-30 \mathrm{mV}$ was found for a $10^{-6} \mathrm{M}$ concentration of bromate, when a $1 \times 10^{-2} \mathrm{M}$ potential buffer containing $0.4 \mathrm{M}$ bromide and $1 \mathrm{M}$ sulfuric acid was used. Since sensitivity enhancement would be expected if a transient potential change could be determined in a timely manner, a flow system was then designed to detect the maximum potential. As a result, a linear calibration for bromate was obtained at a level of $10^{-6} \mathrm{M}$ with a sensitivity $(\mathrm{mV} / \mathrm{mM})$ of $10.6 \times 10^{3}$. This sensitivity was enhanced by 338 -fold compared with that using the change in equilibrium potential, as shown in Table 3. The detection limit $(\mathrm{S} / \mathrm{N}=3)$ was $5 \times 10^{-8} \mathrm{M}$. The sampling rate was $c a .35 \mathrm{samples} / \mathrm{h}$.

Evidence that the origin of the large transient potential change with a mountain-shaped form was the formation and reduction of bromine as an intermediate was confirmed by stopped-flow spectrophotometry [29]. Concretely, in order to confirm the putative reaction pathway and the rate of the reactions (17), (18), (19), the overall reaction rate among $\mathrm{BrO}_{3}{ }^{-}, \mathrm{Fe}^{2+}$, and $\mathrm{Br}^{-}$in sulfuric acid solution and reaction rates of each steps (17), (18), (19) were determined by measuring the bromine concentration. The change in absorbance at $447 \mathrm{~nm}$ was used for the determination of bromine. The bromine concentration-time relation for the absorbance change during the reaction among $\mathrm{BrO}_{3}{ }^{-}, \mathrm{Fe}^{2+}$, and $\mathrm{Br}^{-}$in sulfuric acid solution showed a mountain-shaped form and was in good agreement with that calculated from an equation for a successive first-order reaction using the rates of reactions in (17), (18), and (19). Thus, for the transient potential change, it was verified experimentally that the potential change, namely, the peak height, is proportional to the initial concentration of bromate in a constant reaction time.

Furthermore, repetitive determinations of a large number of trace samples of bromate were proposed by the circulating (closed-loop) FIA (CFIA), which is more suited to the concept of the Zero Emission Research Initiative [30]. The equilibrium potential obtained via the large transient potential change was nearly equal to the initial potential because the concentration of $\mathrm{Fe}(\mathrm{III})-\mathrm{Fe}$ (II) in the potential buffer was sufficiently higher than that of bromate in the sample. For example, even when a $7.0 \mu \mathrm{M}$ bromate solution $(5 \mu \mathrm{L})$ was injected $10^{4}$ times (corresponding to $50 \mathrm{~mL}$ of $7.0 \mu \mathrm{M}$ bromate) into the stream of the circulating reservoir solution $(100 \mathrm{~mL})$ containing $1 \times 10^{-2} \mathrm{M} \mathrm{Fe}(\mathrm{III})-\mathrm{Fe}(\mathrm{II})$ and $0.35 \mathrm{M}$ sodium bromide, the concentration change from $\mathrm{Fe}(\mathrm{II})$ to $\mathrm{Fe}(\mathrm{III})$ was calculated to be only $0.21 \%$, based on (20). This indicates that the change in potential from the initial potential was less than $0.11 \mathrm{mV}$, as calculated from
(21), taking into account the increase in the reservoir volume. Therefore, very large numbers of repetitive determinations of bromate would be carried out using a small volume of reservoir solution in the CFIA system, such as that shown in Figure 4. As a result in experiments, flow signals for the four sets of calibration peaks obtained using $1 \times 10^{-2} \mathrm{M}$ and $1 \times 10^{-3} \mathrm{M} \mathrm{Fe}(\mathrm{III})-\mathrm{Fe}(\mathrm{II})$ potential buffer, respectively, are shown in Figures $4(\mathrm{~A})$ and $4(\mathrm{~B})$. Ten milliliters of a $6.0 \mu \mathrm{M}$ solution and $5 \mathrm{~mL}$ of a $1.0 \mu \mathrm{M}$ bromate solution, corresponding to 2000 and 1000 repetitive injections of $5 \mu \mathrm{L}$ samples, respectively, were added to each reservoir after preparing appropriate calibration peaks. The sensitivities were nearly constant within $5.56-5.32 \mathrm{mV} / \mu \mathrm{M}$ for Figures $4(\mathrm{~A})(\mathrm{a})-(\mathrm{c})$ and $30.9-29.5 \mathrm{mV} / \mu \mathrm{M}$ for Figures $4(\mathrm{~B})(\mathrm{a})-(\mathrm{c})$. Thus, $c a$. 4000 and 2000 repetitive determinations, corresponding to each calibration in Figure 4(A)(c) and Figure 4(B)(c), in which relative sensitivities within 5\% were regarded as acceptable, were possible with high reproducibility using the proposed CFIA method with only $100 \mathrm{~mL}$ of potential buffer solution being required. If $100 \mathrm{~mL}$ of potential buffer were used in the two-channel FIA method reported previously [28], only 65 samples could be determined.

6.2. Analyses of Chromium(VI) and Chromium(III) Using an $\mathrm{Fe}(\mathrm{III})-\mathrm{Fe}(\mathrm{II})$ Potential Buffer Containing Bromide [31, 32]. In batchwise experiments, when chromium(VI) was added to the $\mathrm{Fe}(\mathrm{III})-\mathrm{Fe}(\mathrm{II})$ potential buffer containing bromide in a sulfuric acid solution, the magnitude of the response potential with a mountain-shaped transient change as shown in Figure 2 increased with increasing reaction time. The mechanism of the transient potential change can be attributed to the generation of bromine via the reaction of bromide in the potential buffer with $\mathrm{Cr}(\mathrm{V})$, which was generated as an intermediate during the reaction of $\mathrm{Cr}(\mathrm{VI})$ and $\mathrm{Fe}(\mathrm{II})$. That is, the oxidative conversion of bromide to bromine by $\mathrm{Cr}(\mathrm{VI})$ appears to have been due to $\mathrm{Fe}(\mathrm{II})$, as evidenced by spectrophotometric studies. Thus, the transient potential process can be expressed by (22) and (23). The decrease in potential after a maximum is explained by the progress of reaction (19), that is, the bromine generated in reaction (23) is subsequently consumed:

$$
\begin{aligned}
& \mathrm{Cr}(\mathrm{VI})+\mathrm{Fe}^{2+} \longrightarrow \mathrm{Cr}(\mathrm{V})+\mathrm{Fe}^{3+} \\
& \mathrm{Cr}(\mathrm{V})+2 \mathrm{Br}^{-} \longrightarrow \mathrm{Cr}(\mathrm{III})+\mathrm{Br}_{2}
\end{aligned}
$$

In the flow system used for the determination of $\mathrm{Cr}(\mathrm{VI})$, a two-channel flow system shown Figure 1 was then designed to detect the maximum transient potential [31]. As a result, a linear calibration for chromium(VI) was obtained at a level of $10^{-6} \mathrm{M}$ with a sensitivity $(\mathrm{mV} / \mathrm{mM})$ of $2.6 \times 10^{3}$. This sensitivity was enhanced by 83 -fold compared to that based on the change in equilibrium potential, as shown in Table 2. A detection limit of $2 \times 10^{-8} \mathrm{M} \mathrm{Cr}(\mathrm{VI})$ was achieved using a $1 \times 10^{-4} \mathrm{M} \mathrm{Fe}(\mathrm{III})-\mathrm{Fe}(\mathrm{II})$ potential buffer containing $0.4 \mathrm{M} \mathrm{NaBr}$ and $1.2 \mathrm{M} \mathrm{H}_{2} \mathrm{SO}_{4}$. The R.S.D. was $0.6 \%(n=6)$ for the determination of $1 \times 10^{-6} \mathrm{M} \mathrm{Cr}(\mathrm{VI})$ with a sampling rate of $c a .40 \mathrm{~h}^{-1}$. A variety of heavy metal ions, including $\mathrm{Cr}(\mathrm{III}), \mathrm{Cu}(\mathrm{II}), \mathrm{Zn}(\mathrm{II}), \mathrm{Ni}(\mathrm{II})$, and 

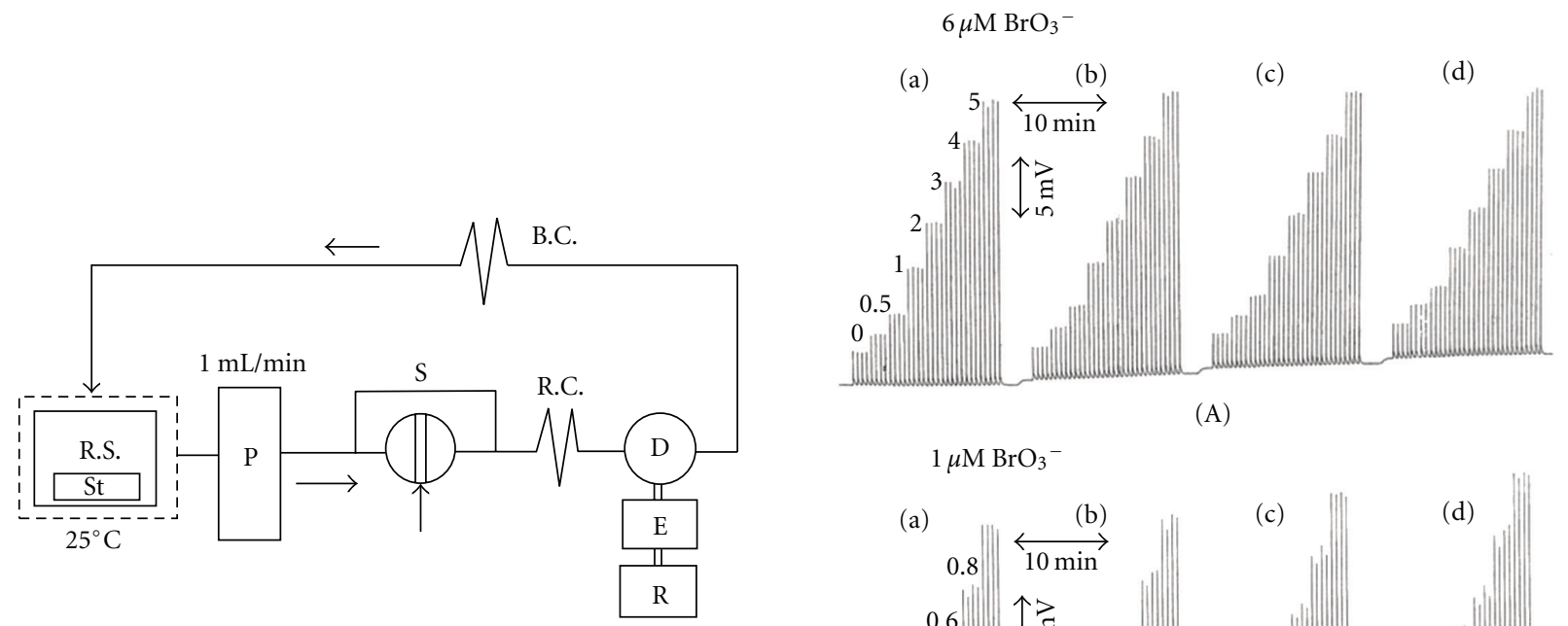

(A)

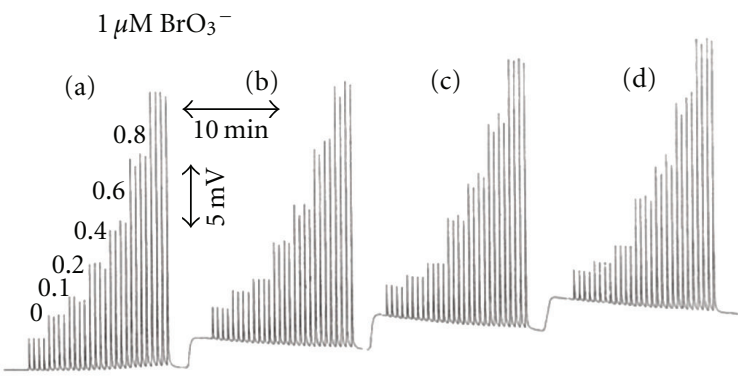

(B)

Figure 4: Schematic diagram of the CFIA system used in this study. R.S: reservoir (100 mL, Fe(III)-Fe(II) $0.35 \mathrm{M} \mathrm{NaBr}$ and $0.2 \%$ $\left(\mathrm{NH}_{4}\right)_{6} \mathrm{Mo}_{7} \mathrm{O}_{24}$ in $\left.1 \mathrm{M} \mathrm{H}_{2} \mathrm{SO}_{4}\right)$; S: sample injection valve $(5 \mu \mathrm{L}$ loop); RC: reaction coil $(13 \mathrm{~cm})$; BC: back pressure coil (3 m); D: the same detectors as in Figure 1. Calibration peaks (A) and (B) for bromate sample obtained by $1 \times 10^{-2} \mathrm{M} \mathrm{Fe}(\mathrm{III})-\mathrm{Fe}(\mathrm{II})$ and $1 \times 10^{-3} \mathrm{M} \mathrm{Fe}(\mathrm{III})-\mathrm{Fe}(\mathrm{II})$ potential buffer, respectively. $10 \mathrm{~mL}$ of $6 \mu \mathrm{M}$ and $5 \mathrm{~mL}$ of $1.0 \mu \mathrm{M}$ bromate sample solutions were added after every calibration (A) and (B), respectively.

$\mathrm{Cd}(\mathrm{II})$, did not interfere with the determination of $\mathrm{Cr}(\mathrm{VI})$ even in the case where their concentration exceeded $10^{2}$ times that of $\mathrm{Cr}(\mathrm{VI})$. The proposed method was designed to meet the Japan standards level for $\mathrm{Cr}(\mathrm{VI})$ in effluent water $(500 \mathrm{ppb})$ and was sufficiently sensitive to use for the precise determination of $\mathrm{Cr}(\mathrm{VI})$ at the $100 \mathrm{ppb}$ level in an actual seawater sample containing $\mathrm{Cr}(\mathrm{VI})$ at the $100 \mathrm{ppb}$ level.

The simultaneous determination of chromium(VI) and chromium(III) in a mixed sample was achieved using a threechannel flow system equipped with a six-way valve, as shown in Figure 5 [32]. The three-channel streams consisted of carrier (water), a reagent $\left(\mathrm{H}_{2} \mathrm{SO}_{4}\right.$ solution or $\mathrm{Ce}(\mathrm{IV})$ solution containing $\mathrm{H}_{2} \mathrm{SO}_{4}$ ), and the $\mathrm{Fe}(\mathrm{III})-\mathrm{Fe}(\mathrm{II})$ potential buffer containing bromide. The six-way valve was used to switch the two reagent streams between the $\mathrm{H}_{2} \mathrm{SO}_{4}$ solution for the selective determination of $\mathrm{Cr}(\mathrm{VI})$ in the sample containing solutions of $\mathrm{Cr}(\mathrm{III})$ and $\mathrm{Ce}(\mathrm{IV})$ in $\mathrm{H}_{2} \mathrm{SO}_{4}$ in order to oxidize $\mathrm{Cr}(\mathrm{III})$ to $\mathrm{Cr}(\mathrm{VI})$ by $\mathrm{Ce}(\mathrm{IV})$ thus permitting the determination of total chromium, as the the sum of $\mathrm{Cr}(\mathrm{VI})$ and $\mathrm{Cr}(\mathrm{III})$. The determination of $\mathrm{Cr}$ (III) in a mixed sample was achieved from the difference in peak height obtained for the two reagent streams. The detection of $\mathrm{Cr}(\mathrm{VI})$ was based on the measurement of a large transient potential change due to the generation of bromine by (22) and (23). A linear calibration was obtained over the range of $1 \times 10^{-6} \mathrm{M}$ to $1 \times 10^{-5} \mathrm{M}$ for $\mathrm{Cr}(\mathrm{VI})$ and from $4 \times 10^{-6} \mathrm{M}$ to $4 \times 10^{-5} \mathrm{M}$ for $\mathrm{Cr}(\mathrm{III})$.
6.3. Analyses of Trace Hydrogen Peroxide and Other Oxidative Species Using Fe(III)-Fe(II) Potential Buffer Containing Bromide [33, 34]. As described in Section 5.1, the determination of high concentrations of hydrogen peroxide by utilizing a large dispersion of a sample zone was achieved using a stream of an $\mathrm{Fe}$ (III)-Fe(II) potential buffer without bromide. While the use of a stream of an $\mathrm{Fe}(\mathrm{III})-\mathrm{Fe}(\mathrm{II})$ potential buffer containing bromide and $\mathrm{Mo}(\mathrm{VI})$ enhanced the sensitivity of the method for hydrogen peroxide, a highly sensitive determination of trace levels of hydrogen peroxide was achieved by detecting the large transient potential change due to the production of bromine as an intermediate [33]. The oxidation of bromide to bromine by hydrogen peroxide occurred very rapidly with the assistance of $\mathrm{Mo}(\mathrm{VI})$ when $\mathrm{Fe}(\mathrm{II})$ was present in the potential buffer in a similar manner to that when bromide is oxidized by $\mathrm{Cr}(\mathrm{V})$ in the presence of $\mathrm{Fe}(\mathrm{II})$, as discussed above. The reaction mechanism for the transient potential change was estimated by batchwise experiments in which hydroxyl radicals, $\mathrm{OH}^{*}$, were generated by the reaction of hydrogen peroxide with $\mathrm{Fe}(\mathrm{II})$ as an intermediate, and the bromide subsequently oxidized to bromine. The elementary reactions for the transient process can be expressed by (24) and (25) for the generation of bromine and (19) for the consumption of bromine. The overall reaction, which is the sum of reactions (24), (25), and (19), is expressed by reaction (26). That is, the presence of bromide in the potential buffer functions as 


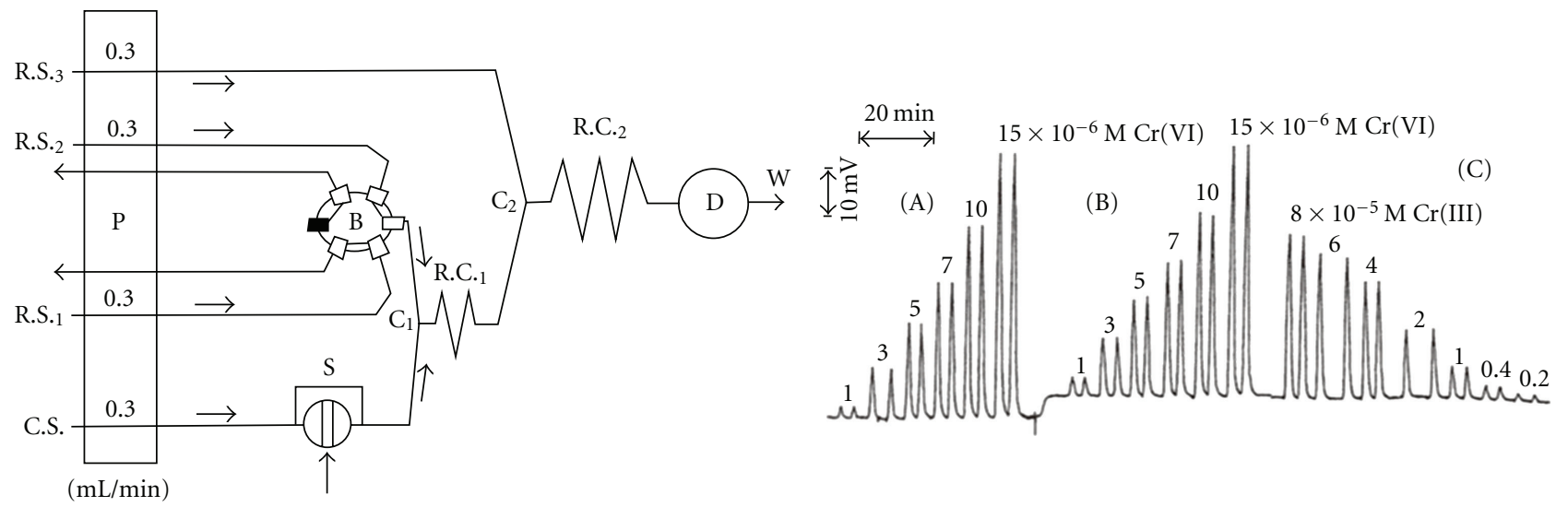

FIgURE 5: Schematic diagram for the simultaneous determination of $\mathrm{Cr}(\mathrm{VI})$ and $\mathrm{Cr}(\mathrm{III})$ and flow injection peaks of $\mathrm{Cr}(\mathrm{VI})$ ((A), (B)) for different reagent solutions and of $\mathrm{Cr}$ (III) (C). C.S: carrier stream (water); R.S. ${ }_{1}$ : reagent solution $1\left(0.05 \mathrm{M} \mathrm{H}_{2} \mathrm{SO}_{4}\right)$; R.S.2 ${ }_{2}$ : reagent solution 2 $\left(2 \times 10^{-4} \mathrm{M} \mathrm{Ce}(\mathrm{IV}), 0.05 \mathrm{M} \mathrm{H}_{2} \mathrm{SO}_{4}\right)$; R.S. .3 : potential buffer solution $\left(1 \times 10^{-2} \mathrm{M} \mathrm{Fe}(\mathrm{III})-\mathrm{Fe}(\mathrm{II}) 0.6 \mathrm{M} \mathrm{NaBr}, 3.6 \mathrm{M} \mathrm{H}_{2} \mathrm{SO}_{4}\right)$; R.C. ${ }_{1}$ : reaction coil $1(230 \mathrm{~cm})$; R.C.2: reaction coil $2(75 \mathrm{~cm})$; B: switching six-way valve.

a homogeneous catalyst for the formation and reduction of bromine:

$$
\begin{gathered}
\mathrm{H}_{2} \mathrm{O}_{2}+\mathrm{Fe}^{2+}+\mathrm{H}^{+} \longrightarrow \mathrm{OH}^{\bullet}+\mathrm{Fe}^{3+}+\mathrm{H}_{2} \mathrm{O} \\
\mathrm{OH}^{\bullet}+\mathrm{Br}^{-}+\mathrm{H}^{+} \longrightarrow \frac{1}{2} \mathrm{Br}_{2}+\mathrm{H}_{2} \mathrm{O} \\
\mathrm{H}_{2} \mathrm{O}_{2}+2 \mathrm{Fe}^{2+}+2 \mathrm{H}^{+} \longrightarrow 2 \mathrm{Fe}^{3+}+2 \mathrm{H}_{2} \mathrm{O}
\end{gathered}
$$

In the flow system involving the detection of a large transient potential change, the sensitivity to hydrogen peroxide was enhanced by 24 -fold compared with that obtained by the detection of the equilibrium potential, as shown in Table 3. The detection limit of $4 \times 10^{-7} \mathrm{M}$ (13.6 ppb) was achieved using a $1 \times 10^{-4} \mathrm{M} \mathrm{Fe}(\mathrm{III})-\mathrm{Fe}(\mathrm{II})$ buffer containing $0.4 \mathrm{M} \mathrm{NaBr}, 1.0 \mathrm{M} \mathrm{H}_{2} \mathrm{SO}_{4}$, and $0.5 \%$ $\left(\mathrm{NH}_{4}\right)_{6} \mathrm{Mo}_{7} \mathrm{O}_{24}$.

Trace amounts of hydrogen peroxide in rainwater play a role in the formation of acid rain. As a result, the development of an analytical method for hydrogen peroxide is an important aspect of atmospheric environmental analysis. This method was applied to the determination of hydrogen peroxide in actual samples of rainwater and was found to provide a good recovery for $\mathrm{H}_{2} \mathrm{O}_{2}$ added to rainwater samples.

Other oxidative species such as chlorite and ozone were also determined by the detection of large transient potential changes [34]. The sensitivities to oxidative species examined in this work increased in the order $\mathrm{H}_{2} \mathrm{O}_{2}<\mathrm{O}_{3}<\mathrm{Cr}(\mathrm{VI})$ $<\mathrm{ClO}_{2}{ }^{-}<\mathrm{BrO}_{3}{ }^{-}$, as shown in Table 3. This sequence of sensitivity most likely depends on the rate of reaction of oxidative species with bromide.

6.4. Analyses of Residual Chlorine and Oxychlorine Species Using $\mathrm{Fe}(\mathrm{III})-\mathrm{Fe}(\mathrm{II})$ Potential Buffer Containing Chloride $[35,36]$. Since oxychlorinated species are considered to be hazardous to human health, the monitoring of levels of residual oxychlorines in drinking water is important for health safety. Furthermore, since $\mathrm{HClO}$ and $\mathrm{ClO}_{2}{ }^{-}$are unstable and easily decomposed by air oxidation, a rapid analytical method that can be operated in a substantially closed system is desirable. A large transient potential change was observed by the generation of chlorine based on (27), (28), and (29) when oxychlorine species, $\mathrm{ClO}_{3}{ }^{-}, \mathrm{ClO}_{2}{ }^{-}$, and $\mathrm{HClO}$, were added to an $\mathrm{Fe}(\mathrm{III})-\mathrm{Fe}(\mathrm{II})$ potential buffer containing chloride, although the magnitude of the potential change was dependent on the reactivity of the oxychlorines. It is noteworthy that the rate of reaction (29) was relatively slower than that of reactions (27) and (28):

$$
\begin{gathered}
\mathrm{HClO}+\mathrm{Cl}^{-}+\mathrm{H}^{+} \longrightarrow \mathrm{Cl}_{2}+\mathrm{H}_{2} \mathrm{O} \\
\mathrm{HClO}_{2}+3 \mathrm{Cl}^{-}+3 \mathrm{H}^{+} \longrightarrow 2 \mathrm{Cl}_{2}+2 \mathrm{H}_{2} \mathrm{O} \\
\mathrm{ClO}_{3}{ }^{-}+5 \mathrm{Cl}^{-}+6 \mathrm{H}^{+} \longrightarrow 3 \mathrm{Cl}_{2}+3 \mathrm{H}_{2} \mathrm{O}
\end{gathered}
$$

In the FIA system, the analytical sensitivity to $\mathrm{HClO}$ and $\mathrm{ClO}_{2}{ }^{-}$obtained by the detection of a transient potential change, where an $\mathrm{Fe}(\mathrm{III})-\mathrm{Fe}(\mathrm{II})$ potential buffer containing chloride was used, was enhanced by $\sim 700$-fold compared with that obtained using an equilibrium potential, as shown in Table 4. The detection limits for $\mathrm{HClO}$ and $\mathrm{ClO}_{2}{ }^{-}$were $5 \times 10^{-8} \mathrm{M}$, when a potential buffer consisting of $5 \times 10^{-4} \mathrm{M}$ $\mathrm{Fe}(\mathrm{III})-1 \times 10^{-3} \mathrm{M} \mathrm{Fe}(\mathrm{II}), 0.3 \mathrm{M} \mathrm{KCl}$ and $0.5 \mathrm{M} \mathrm{H}_{2} \mathrm{SO}_{4}$ (buffer-A) was used. For the determination of $\mathrm{ClO}_{3}^{-}$, a concentration of $10^{-5} \mathrm{M}$ was detected when $9 \mathrm{M} \mathrm{H}_{2} \mathrm{SO}_{4}$ was added to buffer-A, instead of $0.5 \mathrm{M} \mathrm{H}_{2} \mathrm{SO}_{4}$, as shown in the bottom line in Table 4.

The simultaneous determination of $\mathrm{ClO}_{3}{ }^{-}-\mathrm{ClO}_{2}{ }^{-}$or $\mathrm{ClO}_{3}{ }^{-}-\mathrm{HClO}$ (for the case of $\left[\mathrm{ClO}_{3}{ }^{-}\right]>[\mathrm{HClO}]$ and $\left[\mathrm{ClO}_{3}{ }^{-}\right]>\left[\mathrm{ClO}_{2}{ }^{-}\right]$) was achieved using a flow system with dual detectors, as shown in Figure 6(A), where the differences in reactivity of the oxychlorine species with chloride in two potential buffers containing different concentrations of sulfuric acid were utilized. Figures 6(B)(a) and 6(B)(b) show the calibration peaks for $\mathrm{ClO}_{3}{ }^{-}$obtained using detector $\mathrm{D}_{1}$ and for $\mathrm{ClO}_{2}{ }^{-}$obtained using detector $\mathrm{D}_{2}$, respectively, where the mixed sample solutions contained at different concentration but the same molar ratio of $\left[\mathrm{ClO}_{3}{ }^{-}\right] /\left[\mathrm{ClO}_{2}{ }^{-}\right]$was 25 . 


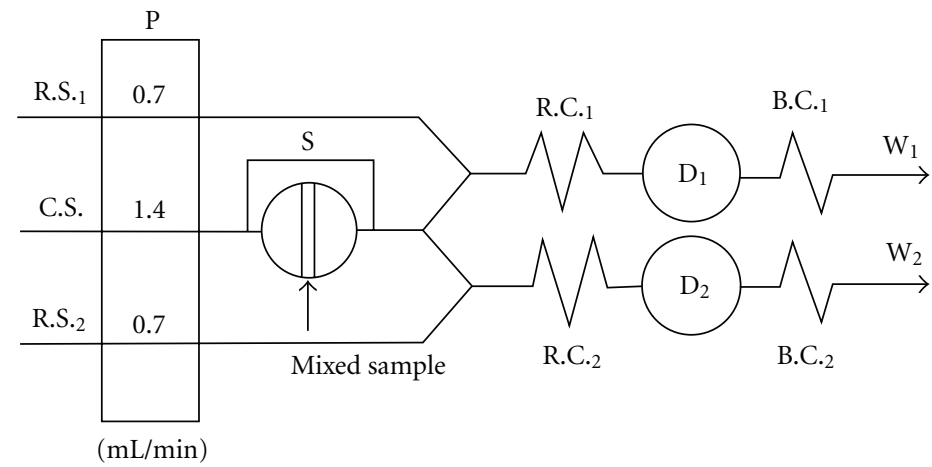

(A)

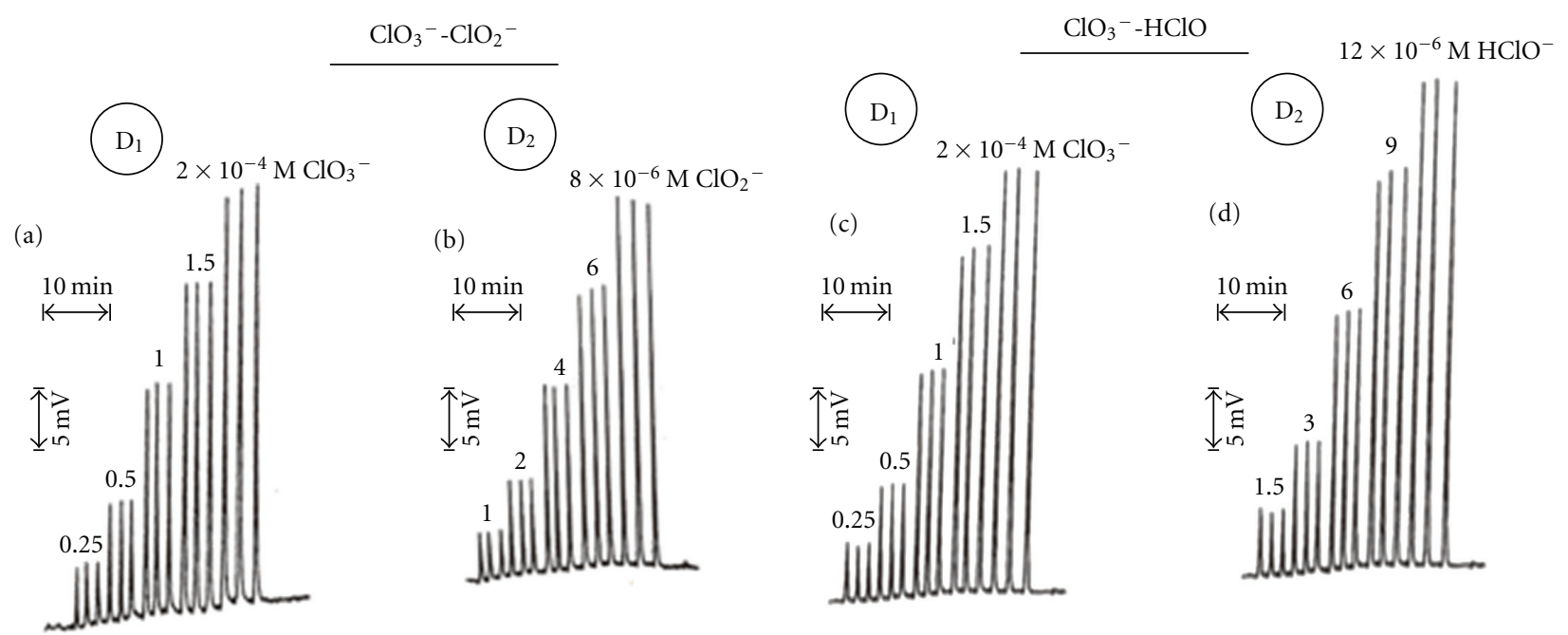

(B)

FIGURE 6: (A) Schematic diagram of a three-channel FIA system for the determination of $\mathrm{ClO}_{3}{ }^{-}-\mathrm{ClO}_{2}{ }^{-}$or $\mathrm{ClO}_{3}{ }^{-}$- $\mathrm{HClO}^{\bullet}$ (for the case of $\left[\mathrm{ClO}_{3}{ }^{-}\right]>[\mathrm{HClO}]$ and $\left.\left[\mathrm{ClO}_{3}{ }^{-}\right]>\left[\mathrm{ClO}_{2}{ }^{-}\right]\right)$. R.S. $._{1}: 5 \times 10^{-3} \mathrm{M} \mathrm{Fe}(\mathrm{III})-1 \times 10^{-2} \mathrm{M} \mathrm{Fe}(\mathrm{II}), 0.3 \mathrm{M} \mathrm{KCl}$ and $9 \mathrm{M} \mathrm{H}_{2} \mathrm{SO}_{4} ; \mathrm{R}^{-\mathrm{S}_{2}}$ : $5 \times 10^{-3} \mathrm{M} \mathrm{Fe}(\mathrm{III})-$ $1 \times 10^{-2} \mathrm{M} \mathrm{Fe}(\mathrm{II}), 0.3 \mathrm{M} \mathrm{KCl}$ and $0.3 \mathrm{M} \mathrm{H}_{2} \mathrm{SO}_{4}$. $\mathrm{D}_{1}$ and $\mathrm{D}_{2}$ : the same detectors as in Figure 1. (B) Calibration peaks $((\mathrm{a}),(\mathrm{b}))$ for $\mathrm{ClO}_{3}{ }^{-}$and $\mathrm{ClO}_{2}{ }^{-}$obtained using detectors $\mathrm{D}_{1}$ and $\mathrm{D}_{2}$, respectively. Concentrations of $\mathrm{ClO}_{3}{ }^{-}$and $\mathrm{ClO}_{2}{ }^{-}$in the mixed sample are indicated in the figure. Calibration peaks ((c), (d)) for $\mathrm{ClO}_{3}{ }^{-}$and $\mathrm{HClO}$ obtained with detector $\mathrm{D}_{1}$ and $\mathrm{D}_{2}$, respectively. Concentrations of $\mathrm{ClO}_{3}{ }^{-}$and $\mathrm{HClO}$ in the mixed sample are indicated in the figure.

TABLE 4: Sensitivities to oxychlorine species.

\begin{tabular}{lccc}
\hline $\begin{array}{l}\text { Oxychlorine } \\
\text { species }\end{array}$ & $\begin{array}{c}\text { Sensitivity }(\mathrm{mV} / \mathrm{mM}) \\
\text { (A) Observed in } \\
\text { FIA system }\end{array}$ & $\begin{array}{c}\text { Enhancement } \\
\text { factor, (A) Calculated }\end{array}$ & \\
\hline $\mathrm{HClO}$ & $1.2 \times 10^{4}$ & $15(m=2)$ & 800 \\
$\mathrm{ClO}_{2}{ }^{-}$ & $2.1 \times 10^{4}$ & $30(m=4)$ & 700 \\
$\mathrm{ClO}_{3}{ }^{-}$ & 3.4 & $45(m=6)$ & 0.08 \\
$\mathrm{ClO}_{3}{ }^{-}$ & $4.3 \times 10^{2 \mathrm{~b}}$ & $45(m=6)$ & 9.8 \\
\hline
\end{tabular}

${ }^{a}$ Sensitivity calculated from (6) using $5 \times 10^{-3} \mathrm{M} \mathrm{Fe}(\mathrm{III})-1 \times 10^{-2} \mathrm{M} \mathrm{Fe}(\mathrm{II})$. bSlope of the calibration curve observed in the FIA system with buffer-A containing $9.0 \mathrm{M} \mathrm{H}_{2} \mathrm{SO}_{4}$ and reaction coil of $200 \mathrm{~cm}$ in length.

Figure $6(\mathrm{~B})(\mathrm{c})$ and $6(\mathrm{~B})(\mathrm{d})$ show the calibration peaks for $\mathrm{ClO}_{3}{ }^{-}$obtained using detector $\mathrm{D}_{1}$ and for $\mathrm{HClO}$ obtained using detector $D_{2}$, respectively, where the concentrations of the mixed sample solutions were different but the molar ratio of $\left[\mathrm{ClO}_{3}{ }^{-}\right] /[\mathrm{HClO}]$ was the same, that is, 16.7 . The method was applied to the determination of residual chlorine in a tap water sample containing a large amount of chlorate and was found to provide an analytical result for $\mathrm{HClO}$, which was in good agreement with that obtained by the $o$-tolidine method. The presence of monochloramine interfered with the determination $\mathrm{HClO}$, since the sensitivity of this method to monochloramine was one-fifth of that to HClO.

Furthermore, under the condition of $\left[\mathrm{ClO}_{3}{ }^{-}\right] \cong[\mathrm{HClO}]$ and $\left[\mathrm{ClO}_{3}{ }^{-}\right] \cong\left[\mathrm{ClO}_{2}{ }^{-}\right]$, the simultaneous determination of mixed oxychlorines was conducted using a four-channel flow system equipped with a cation-exchange column in the Fe(II) form.

6.5. Analysis of Hydrazine Using a Ce(IV)-Ce(III) Potential Buffer [37]. The determination of sub-micromolar levels of hydrazine $\left(\mathrm{N}_{2} \mathrm{H}_{4}\right)$ was accomplished using a two-channel flow system with a $\mathrm{Ce}(\mathrm{IV})-\mathrm{Ce}(\mathrm{III})$ couple in acidic solution 
instead of the $\mathrm{Fe}$ (III)- $\mathrm{Fe}$ (II) couple as a potential buffer solution. The method is based on the measurement of a transient potential change, which appeared in a negative direction. The shape of the transient potential change for hydrazine was different from that observed in the determination of bromate, $\mathrm{Cr}(\mathrm{VI})$, and oxychlorine:

$$
\begin{gathered}
\mathrm{N}_{2} \mathrm{H}_{5}{ }^{+} \rightleftarrows \mathrm{N}_{2} \mathrm{H}_{4}+\mathrm{H}^{+} \quad K=1.02 \times 10^{-8} \\
\mathrm{~N}_{2} \mathrm{H}_{5}{ }^{+} \rightleftarrows \mathrm{N}_{2} \mathrm{H}_{4}+2 \mathrm{H}^{+}+\mathrm{e}^{-} \quad E_{o}>-0.6 \mathrm{~V} \\
\left(\mathrm{H}^{+}+\mathrm{N}_{2} \mathrm{H}_{3} \rightleftarrows \frac{1}{2} \mathrm{~N}_{2}+\mathrm{NH}_{4}^{+}\right) \\
\mathrm{Ce}(\mathrm{IV})+\mathrm{e}^{-} \rightleftarrows \mathrm{Ce}(\mathrm{III})\left(1 \mathrm{M} \mathrm{H}_{2} \mathrm{SO}_{4}\right) \quad E_{0}=1.44 \mathrm{~V} \\
\mathrm{Ce}(\mathrm{IV})+\mathrm{N}_{2} \mathrm{H}_{5}^{+} \longrightarrow \frac{1}{2} \mathrm{~N}_{2}+\mathrm{Ce}(\mathrm{III})+\mathrm{NH}_{4}^{+}+\mathrm{H}^{+}
\end{gathered}
$$

We examined the reaction mechanism for reactions (30), (31), and (32) by spectrophotometric and potentiometric batch experiments, in which the transient potential change was the potential shift from the $\mathrm{Ce}$ (IV)-Ce(III) couple to the $\mathrm{N}_{2} \mathrm{H}_{5}{ }^{+}-\mathrm{N}_{2}$ couple, using a much lower electrode potential during the reaction of hydrazine with $\mathrm{Ce}(\mathrm{IV})$. The overall reaction which is the sum of elementary reactions (31) and (32) can be expressed by (33). The flow system was designed so as to detect the maximum of the transient potential change. Hydrazine, in a wide range of concentrations from $10^{-7} \mathrm{M}$ to $10^{-3} \mathrm{M}$ was determined by appropriately adjusting the concentration of the potential buffer from $10^{-4} \mathrm{M}$ to $10^{-2} \mathrm{M}$, and the detection limit was found to be $1 \times 10^{-7} \mathrm{M}$ (3.2 ppb) when a $2 \times 10^{-4} \mathrm{M} \mathrm{Ce}(\mathrm{IV})-\mathrm{Ce}(\mathrm{III})$ potential buffer was used. The method was capable of determining the concentration of hydrazone in boiler water at the $10 \mathrm{ppb}$ level.

\section{Conclusion}

The proposed potentiometric flow methods, which involve the detection of change in an equilibrium potential or a transient potential, have the potential for using a wide variety of applications, ranging from process control to environmental monitoring. The method is subject to the nature of the redox species under consideration in an analyte sample. Based on our studies, if the redox species react with the components of the potential buffer, the method has the potential for use. However, if the flow system is equipped with an effective scavenger column, to eliminate interfering substance, this promises to expand the applicability of the proposed method to a considerable extent. When the method involves the detection of an intermediate substance, it may also be applicable to the other techniques such as CFIA, batch injections, and potentiometric gas sensors, when a potential buffer that contains bromide or chloride is used.

\section{References}

[1] The Japanese Pharmacopoeia 13th Technical Information, Yakugyo Jiho, 1966.
[2] R. A. Day Jr. and A. L. Underwood, Quentitative Analysis, Prentice Hall, Englewood Cliffs, NJ, USA, 4th edition, 1980.

[3] W. J. Blaedel and R. H. Laessig, "Continuous automated, buretless titrator with direct readout," Analytical Chemistry, vol. 36, no. 8, pp. 1617-1623, 1964.

[4] B. Fleet and A. Y. W. Ho, "Gradient titration-a novel approach to continuous monitoring using ion-selective electrodes," Analytical Chemistry, vol. 46, no. 1, pp. 9-11, 1974.

[5] G. Nagy, K. Tóth, and B. Pungor, "Novel programed coulometric titration technique: chloride determination in streaming solutions," Analytical Chemistry, vol. 47, no. 8, pp. 1460-1462, 1975.

[6] J. Růžička, E. H. Hansen, and H. Mosbaek, "Flow injection analysis. Part IX. A new approach to continuous flow titrations," Analytica Chimica Acta, vol. 92, no. 2, pp. 235-249, 1977.

[7] A. U. Ramsing, J. Růžička, and E. H. Hansen, "The principles and theory of high-speed titrations by flow injection analysis," Analytica Chimica Acta, vol. 129, no. C, pp. 1-17, 1981.

[8] O. Åström, "Single-point titrations. Part 4. Determination of acids and bases with flow injection analysis," Analytica Chimica Acta, vol. 105, pp. 67-75, 1979.

[9] R. A. De Sousa, F. S. Semaan, J. A. F. Baio, and E. T. G. Cavalheiro, "Fast determination of minoxidil by photometric flow titration," Ecletica Quimica, vol. 30, no. 3, pp. 79-84, 2005.

[10] J. Ruzicka and E. H. Hansen, Flow-Injection Analysis, John Wiley \& Sons, New York, NY, USA, 1981.

[11] T. Imato and N. Ishibashi, "Flow injection analysis of concentrated aqueous solution of strong acids and bases," Analytical Sciences, vol. 1, pp. 481-482, 1985.

[12] N. Ishibashi and T. Imato, "Flow injection analysis by using acid-base or metal-ligand buffers and color-indicators," Fresenius' Zeitschrift für Analytische Chemie, vol. 323, no. 3, pp. 244-248, 1986.

[13] D. G. Porter and R. Sawyer, "The automatic determination of sugars in foodstuffs by a continuous flow technique with a redox detector," The Analyst, vol. 97, no. 1156, pp. 569-575, 1972.

[14] K. Brunt, "Comparison between the performances of an electrochemical detector flow cell in a potentiometric and an amperometric measuring system using glucose as a test compound," The Analyst, vol. 107, no. 1279, pp. 1261-1271, 1982.

[15] BO. Karlberg and S. Thelander, "Determination of readily oxidised compounds by flow injection analysis and redox potential detection," The Analyst, vol. 103, no. 1232, pp. 11541159, 1978.

[16] H. Ohura, T. Imato, S. Yamasaki, and N. Ishibashi, "Potentiometric flow injection analysis of redox compounds using redox potential buffers," Journal of Flow Injection Analysis, vol. 8, pp. 2-20, 1991.

[17] T. Imato, H. Ohura, S. Yamasaki, and Y. Asano, "Potentiometric flow injection analysis of concentrated hydrogen peroxide by using an $\mathrm{Fe}(\mathrm{II})-\mathrm{Fe}(\mathrm{III})$ redox potential buffer solution," Talanta, vol. 52, no. 1, pp. 19-26, 2000.

[18] T. Imato, H. Ohura, Y. Asano, N. Yamasaki, and N. Ishibashi, "Determination of ethanol in alcoholic beverages by gasdiffusion/FIA," Bunseki Kagaku, vol. 37, pp. T105-T108, 1988.

[19] H. Ohura, T. Imato, Y. Asano, N. Yamasaki, and N. Ishibashi, "Potentiometric determination of ethanol in alcoholic beverages using a flow injection analysis system equipped with a gas diffusion unit with a microporous poly(tetrafluoroethylene) membrane," Analytical Sciences, vol. 6, pp. 541-545, 1990. 
[20] H. Ohura, T. Imato, Y. Asano, N. Yamasaki, and N. Ishibashi, "Potentiometric FIA of disaccharides using the hexacyanoferrate(III)-hexacyanoferrate(II) potential buffer solution," Bunseki Kagaku, vol. 35, pp. 807-813, 1986.

[21] H. Ohura, T. Imato, N. Yamasaki, and N. Ishibashi, "Potentiometric flow injection analysis of glucose using hexacyanoferrate(III)-hexacyanoferrate(II) potential buffer," Analytical Sciences, vol. 3, pp. 453-456, 1987.

[22] H. Ohura, T. Imato, N. Yamasaki, and N. Ishibashi, "Potentiometric determination of reducing sugars as borate complexes using hexacyanoferrate(III)-hexacyanoferrate(II) potential buffer and its application to liquid chromatography," Analytical Sciences, vol. 6, pp. 777-779, 1990.

[23] H. Ohura, T. Imato, H. Egawa, N. Yamasaki, and N. Ishibashi, "Potentiometric flow injection determination of sucrose by using immobilized enzymes column and hexacyanoferrate(III)-hexacyanoferrate(II) potential buffer," Bulletin of the Faculty of Engineering Kyushu Sangyo University, vol. 26, pp. 49-56, 1989.

[24] H. Ohura, T. Imato, Y. Asano, and S. Yamasaki, "Potentiometric flow injection determination of amylase activity by using hexacyanoferrate(III)-hexacyanoferrate(II) potential buffer," Talanta, vol. 45, no. 3, pp. 565-573, 1998.

[25] H. Ohura, Y. Ishibashi, T. Imato, and S. Yamasaki, "Potentiometric flow injection determination of manganese(II) by using a hexacyanoferrate(III)-hexacyanoferrate(II) potential buffer," Talanta, vol. 60, no. 1, pp. 177-184, 2003.

[26] H. Ohura, T. Imato, N. Yamasaki, and N. Ishibashi, "Potentiometric FIA of trace phenol," Bunseki Kagaku, vol. 40, pp. 93-96, 1991.

[27] H. Ohura, T. Imato, H. Nakashima, N. Yamasaki, and N. Ishibashi, "Potentiometric flow injection analysis of some phenols by bromination reaction," Bulletin of the Faculty of Engineering Kyushu Sangyo University, vol. 27, pp. 53-57, 1990.

[28] H. Ohura, T. Imato, N. Yamasaki, and N. Ishibashi, "Potentiometric flow injection analysis of trace bromate based on its redox reaction with an iron(III)-iron(II) buffer solution containing bromide," Bunseki Kagaku, vol. 35, pp. 349-355, 1986.

[29] H. Ohura, T. Imato, N. Yamasaki, and N. Ishibashi, "Kinetic approach to reaction among bromate, bromide and iron(II) utilized for potentiometric flow injection analysis of trace bromate based on its redox reaction with iron(III)-iron(II) buffer," Nippon Kagaku Kaishi, vol. 8, pp. 797-803, 1992.

[30] H. Ohura, T. Imato, K. Kameda, and S. Yamasaki, "Potentiometric determination of bromate using an $\mathrm{Fe}(\mathrm{III})-\mathrm{Fe}(\mathrm{II})$ potential buffer by circulatory flow injection analysis," Analytical Sciences, vol. 20, no. 3, pp. 513-518, 2004.

[31] H. Ohura, T. Imato, K. Kameda, and S. Yamasaki, "Potentiometric FIA of chromium(VI) in seawater," Bunseki Kagaku, vol. 43, pp. 31-37, 1994.

[32] H. Ohura, T. Imato, I. Matsuo, and S. Yamasaki, "Sequential determination of chromium (VI) and chromium (III) by potentiometric flow-injection method," Bunseki Kagaku, vol. 49, no. 1, pp. 59-61, 2000.

[33] H. Ohura, T. Imato, S. Yamasaki, and N. Ishibashi, "Potentiometric flow-injection determination of trace hydrogen peroxide based on its induced reaction in iron(III)-iron(II) potential buffer containing bromide and molybdenum(VI)," Talanta, vol. 43, no. 6, pp. 943-950, 1996.

[34] N. Ishibashi, T. Imato, S. Yamasaki, and H. Ohura, "Sensitivity enhancement by potentiometric flow-injection analysis based on redox reaction with an iron(III) - iron(II) buffer," Analytica Chimica Acta, vol. 261, no. 1-2, pp. 405-410, 1992.

[35] N. Ishibashi, T. Imato, H. Ohura, and S. Yamasaki, "Potentiometric flow-injection determination of trace chlorine based on its redox reaction with an iron(III)/iron(II) buffer," Analytica Chimica Acta, vol. 214, no. C, pp. 349-357, 1988.

[36] H. Ohura, T. Imato, and S. Yamasaki, "Simultaneous potentiometric determination of $\mathrm{CIO}_{3}{ }^{-}{ }_{-} \mathrm{CIO}_{2}{ }^{-}$and $\mathrm{CIO}_{3}{ }^{-}-\mathrm{HClO}$ by flow injection analysis using $\mathrm{Fe}$ (III)-Fe(II) potential buffer," Talanta, vol. 49, no. 5, pp. 1003-1015, 1999.

[37] H. Ohura, T. Imato, and S. Yamasaki, "Potentiometric/flowinjection determination of trace hydrazine and its application to boiler water," Bunseki Kagaku, vol. 45, no. 7, pp. 689-695, 1996. 


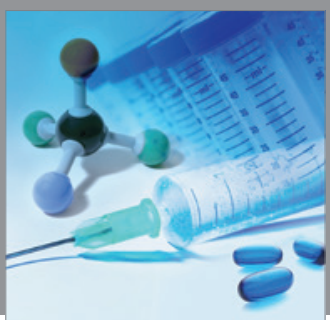

International Journal of

Medicinal Chemistry

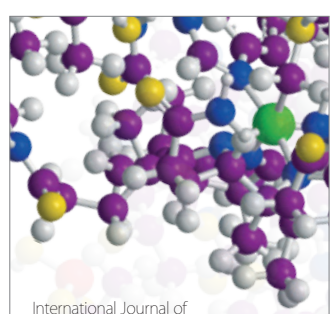

Carbohydrate Chemistry

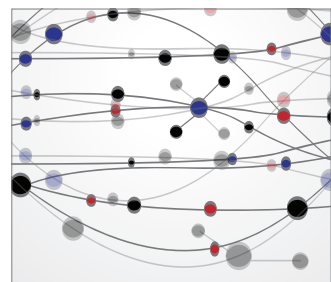

The Scientific World Journal
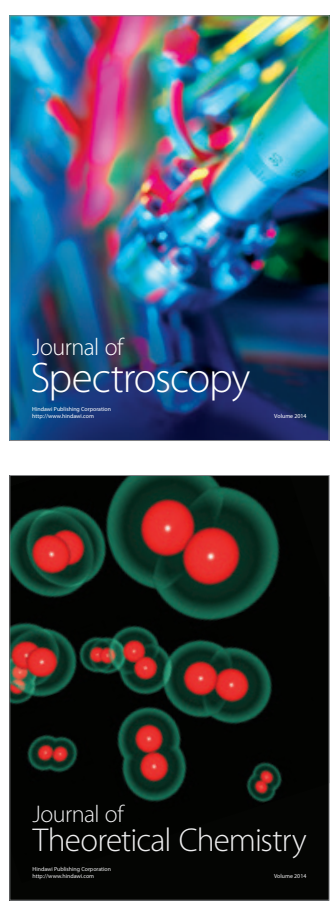
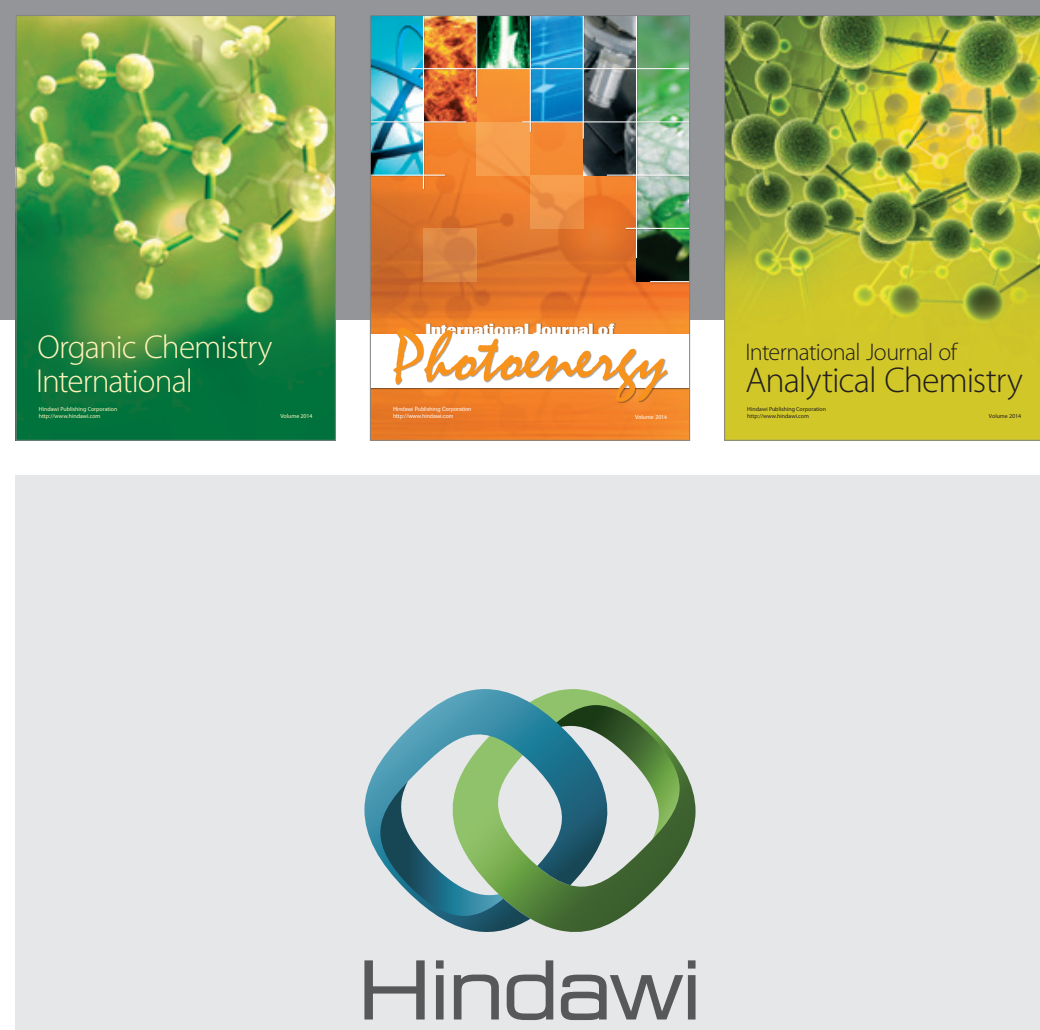

Submit your manuscripts at

http://www.hindawi.com
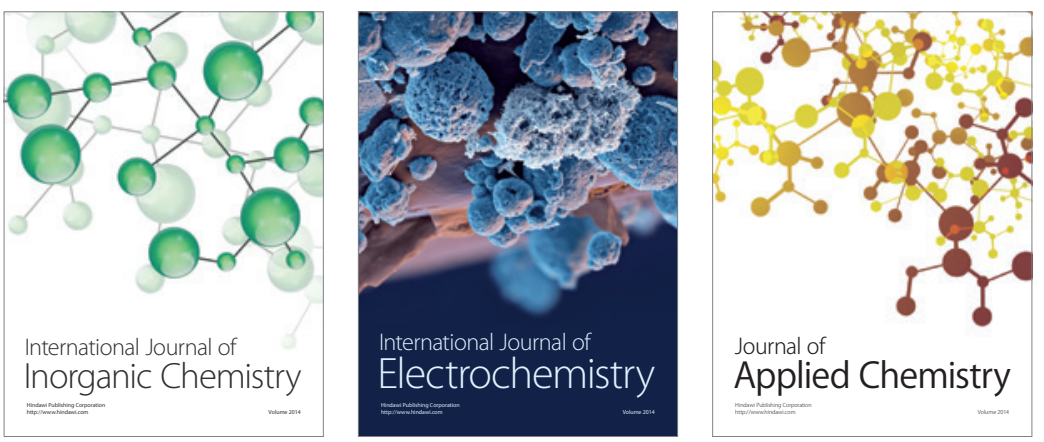

Journal of

Applied Chemistry
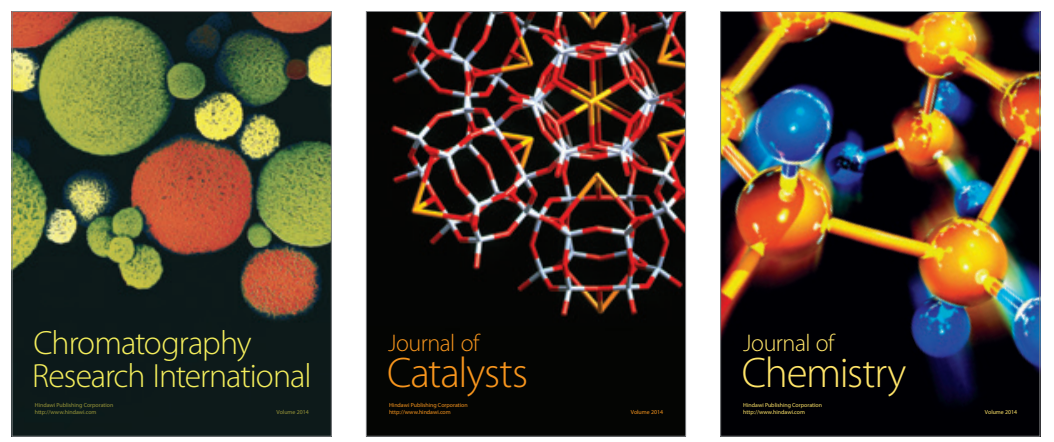
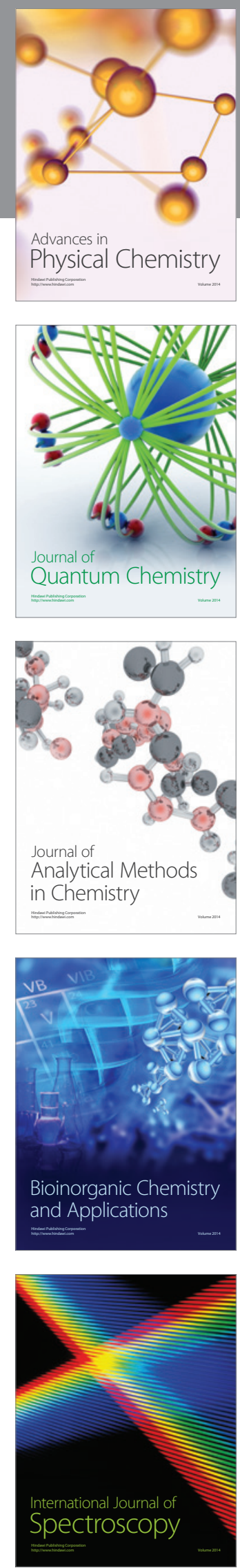